\title{
Training-Associated Emotional Arousal Shapes Endocannabinoid Modulation of Spatial Memory Retrieval in Rats
}

\author{
@Maria Morena, ${ }^{1,2,3}$ Valentina De Castro, ${ }^{1}$ J. Megan Gray, ${ }^{2,3}$ Maura Palmery, ${ }^{1}$ Viviana Trezza, ${ }^{4}$ Benno Roozendaal, ${ }^{5,6}$ \\ Matthew N. Hill, ${ }^{2,3}$ and Patrizia Campolongo ${ }^{1}$ \\ ${ }^{1}$ Department of Physiology and Pharmacology, Sapienza University of Rome, 00185 Rome, Italy, ${ }^{2}$ Hotchkiss Brain Institute and ${ }^{3}$ Departments of Cell \\ Biology and Anatomy and Psychiatry, University of Calgary, Calgary, Alberta T2N 4N1, Canada, ${ }^{4}$ Department of Science, Section of Biomedical Sciences and \\ Technologies, University Roma Tre, 00146 Rome, Italy, and ${ }^{5}$ Department of Cognitive Neuroscience, Radboud University Medical Center and ${ }^{6}$ Donders \\ Institute for Brain, Cognition and Behaviour, Radboud University Nijmegen, 6525 EZ Nijmegen, The Netherlands
}

Variations in environmental aversiveness influence emotional memory processes in rats. We have previously shown that cannabinoid effects on memory are dependent on the stress level at the time of training as well as on the aversiveness of the environmental context. Here, we investigated whether the hippocampal endocannabinoid system modulates memory retrieval depending on the trainingassociated arousal level. Male adult Sprague Dawley rats were trained on a water maze spatial task at two different water temperatures $\left(19^{\circ} \mathrm{C}\right.$ and $\left.25^{\circ} \mathrm{C}\right)$ to elicit either higher or lower stress levels, respectively. Rats trained under the higher stress condition had better memory and higher corticosterone concentrations than rats trained at the lower stress condition. The cannabinoid receptor agonist WIN55212-2 (10-30 ng/side), the 2-arachidonoyl glycerol (2-AG) hydrolysis inhibitor JZL184 (0.1-1 $\mu \mathrm{g} / \mathrm{side})$, and the anandamide (AEA) hydrolysis inhibitor URB597 (10-30 ng/side) were administered bilaterally into the hippocampus 60 min before probe-trial retention testing. WIN55212-2 or JZL184, but not URB597, impaired probe-trial performances only of rats trained at the higher stressful condition. Furthermore, rats trained under higher stress levels displayed an increase in hippocampal 2-AG, but not AEA, levels at the time of retention testing and a decreased affinity of the main 2-AG-degrading enzyme for its substrate. The present findings indicate that the endocannabinoid 2-AG in the hippocampus plays a key role in the selective regulation of spatial memory retrieval of stressful experience, shedding light on the neurobiological mechanisms involved in the impact of stress effects on memory processing.

Key words: cannabinoid receptors; emotional arousal; endocannabinoids; memory for emotional experiences; stress

\section{Significance Statement}

Endogenous cannabinoids play a central role in the modulation of memory for emotional events. Here we demonstrate that the endocannabinoid 2-arachidonoylglycerol in the hippocampus, a brain region crucially involved in the regulation of memory processes, selectively modulates spatial memory recall of stressful experiences. Thus, our findings provide evidence that the endocannabinoid 2-arachidonoylglycerol is a key player in mediating the impact of stress on memory retrieval. These findings can pave the way to new potential therapeutic intervention for the treatment of neuropsychiatric disorders, such as post-traumatic stress disorder, where a previous exposure to traumatic events could alter the response to traumatic memory recall leading to mental illness.

\section{Introduction}

Extensive evidence indicates that the endocannabinoid system regulates cognitive function (Wotjak, 2005; Campolongo et al., 2009a; Kano et al., 2009; Marsicano and Lafenêtre, 2009; Akirav,

Received May 22, 2015; revised Aug. 5, 2015; accepted Aug. 28, 2015

Author contributions: M.M., V.T., B.R., M.N.H., and P.C. designed research; M.M., V.D.C., J.M.G., M.P., V.T., M.N.H., and P.C. performed research; M.M., V.D.C., M.N.H., and P.C. analyzed data; M.M., B.R., and P.C. wrote the paper.
2011). Endocannabinoids, mainly $N$-arachidonoyl ethanolamine (anandamide, AEA) and 2-arachidonoyl glycerol (2-AG), are synthesized on demand and travel retrogradely to presynaptic sites to bind G-protein-coupled cannabinoid receptors type 1 
(CB1) (Herkenham et al., 1990; Matsuda et al., 1990; Devane et al., 1992; Sugiura et al., 1995; Kano et al., 2009). AEA and 2-AG are subsequently degraded mainly by fatty acid amide hydrolase (FAAH) and monoacylglycerol lipase (MAGL), respectively (Kano et al., 2009). CB1 receptors are highly expressed within corticolimbic brain areas, such as the hippocampus, basolateral complex of the amygdala (BLA), and prefrontal cortex (Herkenham et al., 1991; Tsou et al., 1998), where they predominately modulate both excitatory and inhibitory signaling within specific neuronal circuits involved in learning and memory processes for emotionally arousing experiences (Wotjak, 2005; Campolongo et al., 2009a; Kano et al., 2009; Marsicano and Lafenêtre, 2009; Akirav, 2011). Although evidence regarding cannabinoid effects on memory retrieval is limited, the majority of studies show that exogenous cannabinoid agonists induce detrimental effects on memory retrieval when either administered systemically (Mishima et al., 2001; Niyuhire et al., 2007; Wise et al., 2009) or into discrete brain areas, such as the hippocampus (Piri and Zarrindast, 2011; Segev and Akirav, 2011; Atsak et al., 2012) or BLA (Segev and Akirav, 2011).

The endocannabinoid system plays a key role in the control of emotional responses to environmental challenges (Zanettini et al., 2011; Ruehle et al., 2012; Gunduz-Cinar et al., 2013; Morena and Campolongo, 2014). We have previously reported that cannabinoids induce different effects on memory depending on the aversiveness of the environmental conditions and the stress level at the time of training (Campolongo et al., 2013). Further, we have recently demonstrated that endocannabinoids are physiologically released in limbic brain regions only when animals are trained under high arousal conditions (Morena et al., 2014). Variations in environmental aversiveness differentially influence spatial memory processes in rats (Sandi et al., 1997; Akirav et al., 2004; Salehi et al., 2010). Salehi et al. (2010) induced different stress levels by training rats on a radial-arm water maze task at three different water temperatures $\left(25^{\circ} \mathrm{C}, 19^{\circ} \mathrm{C}\right.$, and $\left.16^{\circ} \mathrm{C}\right)$. An inverted-U shape effect was found, with animals trained at $19^{\circ} \mathrm{C}$ showing better memory than animals trained at either the higher $\left(16^{\circ} \mathrm{C}\right)$ or lower $\left(25^{\circ} \mathrm{C}\right)$ stress condition (Salehi et al., 2010). Once memories are consolidated, the efficacy or accuracy of the information retrieved is vulnerable to stress effects at the time of recall.

Considerable evidence points to the hippocampus as a brain structure of crucial importance for retrieval of spatial memory (Hirsh, 1974; Moser and Moser, 1998; Holt and Maren, 1999; Riedel et al., 1999; Eldridge et al., 2000; Brun et al., 2002; MatusAmat et al., 2004). Stress or exogenous glucocorticoid administration typically impairs memory retrieval of contextual/spatial information in rats and declarative information in humans (de Quervain et al., 1998; Roozendaal et al., 2003, 2004a; de Quervain et al., 2009). The endocannabinoid 2-AG in the dorsal hippocampus plays an intermediary role in mediating glucocorticoid effects on the impairment of contextual memory retrieval (Atsak et al., 2012).

Here, we investigated whether the hippocampal endocannabinoid system is differentially involved in regulating spatial memory retrieval of rats trained at two experimental conditions that differed with respect to their environment-associated stress lev-

The authors declare no competing financial interests.

Correspondence should be addressed to either Dr. Maria Morena or Dr. Patrizia Campolongo, Department of Physiology and Pharmacology, Sapienza University of Rome, P.le Aldo Moro 5, 00185 Rome, Italy. E-mail: maria.morena@uniroma1.it or patrizia.campolongo@uniroma1.it.

DOI:10.1523/JNEUROSCI.1983-15.2015

Copyright $\odot 2015$ the authors $\quad 0270-6474 / 15 / 3513963-13 \$ 15.00 / 0$ els. Rats were trained on a water maze spatial task at two different water temperatures $\left(19^{\circ} \mathrm{C}\right.$ and $\left.25^{\circ} \mathrm{C}\right)$ to elicit either a higher or lower level of stress. Before retention testing, we pharmacologically manipulated the endocannabinoid system by administering the cannabinoid receptor agonist WIN55212-2, the 2-AG hydrolysis inhibitor JZL184, or the AEA hydrolysis inhibitor URB597 directly into the dorsal hippocampus. Behavioral experiments were paralleled by biochemical measurement of plasma corticosterone levels, hippocampal 2-AG and AEA content, and the cannabinoid hydrolytic enzymatic machinery.

\section{Materials and Methods}

Animals. Male adult Sprague Dawley rats (320-370 g at the time of behavioral experiments; Charles River Breeding Laboratories) were housed individually in a temperature-controlled $\left(20 \pm 1^{\circ} \mathrm{C}\right)$ vivarium room and maintained under a $12 \mathrm{~h} / 12 \mathrm{~h}$ light/dark cycle (7:00 A.M. to 7:00 P.M. lights on). Food and water were available ad libitum. Training and testing were performed during the light phase of the cycle between 10:00 A.M. and 4:00 P.M. All experimental procedures were in compliance with the European Union Directive on the protection of animals used for scientific purposes (2010/63/EU), the Italian law (D.L. 26/2014), the Declaration of Helsinki, and the Guide for the Care and Use of Mammals in Neuroscience and Behavioral Research (National Research Council, 2004).

Surgery. The rats were anesthetized with sodium pentobarbital (50 $\mathrm{mg} / \mathrm{kg}$, i.p. $)$ and given atropine sulfate $(0.4 \mathrm{mg} / \mathrm{kg}$, i.p.) to maintain respiration. Subsequently, they were injected with $3 \mathrm{ml}$ of saline (s.c.) to facilitate clearance of these drugs and prevent dehydration. The rats were then positioned in a stereotaxic frame (David Kopf Instruments), and two stainless-steel guide cannulae (23 gauge, 11 -mm-long) were implanted bilaterally with the cannula tips $1.5 \mathrm{~mm}$ above the CA1 region of the dorsal hippocampus (coordinates: anteroposterior, $-3.4 \mathrm{~mm}$; mediolateral, $\pm 1.8 \mathrm{~mm}$; dorsoventral, $-2.7 \mathrm{~mm}$ ) according to the atlas of Paxinos and Watson (2005). The cannulae were affixed to the skull with two anchoring screws and dental cement. Stylets (11-mm-long 00 insect dissection pins) were inserted into each cannula to maintain patency. After surgery, the rats were retained in an incubator until recovered from anesthesia and were then returned to their home cages. Rats were allowed to recover from surgery for $10 \mathrm{~d}$ before training and were handled $1 \mathrm{~min}$ per day for $3 \mathrm{~d}$ before training.

Water maze spatial task and experimental procedures. The experimental apparatus was a circular black galvanized tank, $1.83 \mathrm{~m}$ in diameter and $0.6 \mathrm{~m}$ in height, filled with water to a depth of $20 \mathrm{~cm}$. The maze was located in a room containing many salient, visual, extra-maze cues. A rectangular platform $(20 \mathrm{~cm} \times 25 \mathrm{~cm})$ was placed at a fixed location 25 $\mathrm{cm}$ away from the edge of the pool and $2.5 \mathrm{~cm}$ below the water surface. A slightly modified procedure of those described by Akirav et al. (2004) and Campolongo et al. (2009b) was used. Separate groups of animals were trained at a water temperature of either $19^{\circ} \mathrm{C}$ or $25^{\circ} \mathrm{C}$, which were previously shown to elicit different stress levels and cognitive performance in rats (Akirav et al., 2004; Salehi et al., 2010). On each day of training, the rats were carried from the vivarium to the experimental room, and training began 120 min later. For spatial training, the rats were given four trials on each daily session for two consecutive days. This relatively small number of trials was chosen such that the animals acquired the task but that their retention performance was moderate to avoid any potential ceiling or floor effects. Before the first training trial, each rat was placed directly onto the submerged platform for $15 \mathrm{~s}$. For each trial, the rat was placed into the tank at one of the four designated starting points and allowed to find the platform. If an animal failed to find the platform within $60 \mathrm{~s}$, it was manually guided to the platform. After mounting the platform, the rat was allowed to remain there for $10 \mathrm{~s}$ and was then placed into a holding cage for $25 \mathrm{~s}$ until the start of the next trial. The time each rat spent searching for the platform was recorded as the escape latency. Retention of the spatial training was assessed $24 \mathrm{~h}$ after the last training session with a $60 \mathrm{~s}$ free-swim probe trial under equal temperature conditions $\left(22 \pm 0.5^{\circ} \mathrm{C}\right)$. During the probe trial, the platform was removed from the tank, and a new starting position was used. Training and probe 
trials were videotaped, and an automated tracking system (Smart-BS, Panlab S.L.U., Barcelona, Spain) was used to analyze the swim path of each subject and calculate several corresponding dependent measures, such as time spent in the quadrant containing the platform during training (target quadrant), time spent in the quadrant opposite to the target quadrant (opposite quadrant), initial latency to cross the platform location, number of crossings through the platform location, and total swim distance. The target and opposite quadrants were equidistant from the starting position on the probe trial.

Drug treatment. The CB1 receptor agonist WIN55212-2 (10 or $30 \mathrm{ng}$ in $0.5 \mu \mathrm{l})$, the 2 -AG hydrolysis inhibitor JZL184 $(0.1$ or $1 \mu \mathrm{g}$ in $0.5 \mu \mathrm{l})$, or the AEA hydrolysis inhibitor URB597 (10 or $30 \mathrm{ng}$ in $0.5 \mu \mathrm{l}$ ) was administered into the dorsal hippocampus $60 \mathrm{~min}$ before the probe trial. To examine whether WIN55212-2 and JZL184 effects were mediated via an activation of CB1 receptors, other groups of rats were administered the effective dose of WIN55212-2 (10 ng in $0.5 \mu \mathrm{l})$ or JZL184 ( $1 \mu \mathrm{g}$ in $0.5 \mu \mathrm{l})$ together with the CB1 receptor antagonist AM251 at a dose nonaltering memory performance per se $(0.28 \mathrm{ng})$. Doses were selected on the basis of previous and pilot experiments performed in our laboratory (Morena et al., 2014). All drugs were dissolved in a vehicle containing 5\% polyethylene glycol, $5 \%$ Tween 80 , and $90 \%$ saline. Bilateral infusions of drugs or an equivalent volume of vehicle into the dorsal hippocampus were made by using a 30-gauge injection needle connected by polyethylene tubing (PE-20) to a $10 \mu \mathrm{l}$ Hamilton microsyringe driven by a minipump (KD Scientific). The injection needle protruded $1.5 \mathrm{~mm}$ beyond the tip of the cannula, and a $0.5 \mu \mathrm{l}$ injection volume per hemisphere was infused over a period of $50 \mathrm{~s}$ (Roozendaal et al., 2004b; Atsak et al., 2012). The injection needles were retained within the cannulae for an additional $20 \mathrm{~s}$ after drug infusion to maximize diffusion and to prevent backflow of drug into the cannulae. All drugs were kindly donated by the National Institute of Mental Health, and drug solutions were freshly prepared before each experiment.

Histology. The rats were anesthetized with an overdose of sodium pentobarbital (100 mg/kg, i.p.) and perfused transcardially with $0.9 \%$ saline. The brains were then removed and immersed in a $4 \%$ formaldehyde solution. At least $48 \mathrm{~h}$ before sectioning, the brains were transferred to a $20 \%$ sucrose solution in saline for cryoprotection. Coronal sections of $35 \mu \mathrm{m}$ were cut on a cryostat, mounted on gelatin-coated slides, and stained with cresyl violet. The sections were examined under a light microscope (Microscope Nikon 801), and determination of the location of infusion needle tips within the hippocampus was made according to the standardized atlas plates of Paxinos and Watson (2005) by an observer blind to drug treatment condition. For all experiments, only rats with needle tips terminating within the CA1 region of the hippocampus were included in the data analysis. Approximately $5 \%$ of the animals were excluded because of either cannula misplacement or damage to the targeted tissue.

Plasma corticosterone levels. Plasma corticosterone levels were determined in parallel groups of rats handled for $3 \mathrm{~d}$ and subsequently trained at a water temperature of either $19^{\circ} \mathrm{C}$ or $25^{\circ} \mathrm{C}$. Control animals were handled for $3 \mathrm{~d}$ but were not trained or tested. Rats were euthanized 20 min after the two training sessions or immediately after the probe trial. After decapitation, trunk blood was collected and samples were centrifuged at $1900 \times g$ for $20 \mathrm{~min}$ at $4^{\circ} \mathrm{C}$. Plasma was stored at $-20^{\circ} \mathrm{C}$ and analyzed for corticosterone using an ELISA kit (Assay Designs) according to the manufacturer's instructions. The kit sensitivity and detection limit are 18.6 and $16.9 \mathrm{pg} / \mathrm{ml}$, respectively. The CV values for intra-assay and interassay precision are $5.2 \%$ and $8.7 \%$, respectively.

Endocannabinoid extraction and analysis. To examine whether 2-AG and AEA are physiologically released into the hippocampus during memory retrieval, separate groups of nonoperated rats were trained at the two different water temperatures $\left(19^{\circ} \mathrm{C}\right.$ or $\left.25^{\circ} \mathrm{C}\right)$ and euthanized immediately after the probe trial. Control animals were handled but not trained or tested. After rapid decapitation, hippocampi were rapidly dissected and stored at $-80^{\circ} \mathrm{C}$. The lipid extraction process was performed by using a slightly modified procedure of that described by Dincheva et al. (2015). Brain tissue was weighed and placed into borosilicate glass culture tubes containing $2 \mathrm{ml}$ of acetonitrile with 5 pmol of $\left[{ }^{2} \mathrm{H}_{8}\right]$ AEA and $5 \mathrm{nmol}$ of $\left[{ }^{2} \mathrm{H}_{8}\right]$ 2-AG for extraction, and homogenized with a glass rod. Tissue was sonicated for $30 \mathrm{~min}$ on ice water and incubated overnight at $-20^{\circ} \mathrm{C}$ to precipitate proteins, then centrifuged at $1500 \times g$ to remove particulates. The supernatants were transferred to a new glass tube and evaporated to dryness under $\mathrm{N}_{2}$ gas. The samples were reconstituted in $300 \mu \mathrm{l}$ of acetonitrile and dried again under $\mathrm{N}_{2}$ gas. Lipid extracts were suspended in $20 \mu$ l of acetonitrile and stored at $-80^{\circ} \mathrm{C}$ until analysis. Analysis of AEA and 2-AG was performed by liquid chromatography mass spectrometry analysis as previously detailed (Dincheva et al., 2015).

Membrane preparation. Immediately after the probe trial, following rapid decapitation, the hippocampi were dissected from nonoperated rats trained at a water temperature of $19^{\circ} \mathrm{C}$ or $25^{\circ} \mathrm{C}$ and from control rats that were handled but not trained or tested. Brain samples were stored at $-80^{\circ} \mathrm{C}$. Membranes were collected by homogenization of frozen tissue in 10 volumes of TME buffer ( 50 mM Tris $\mathrm{HCl}, \mathrm{pH} 7.4 ; 1$ mм EDTA, and $3 \mathrm{~mm} \mathrm{MgCl}_{2}$ ) (Hill et al., 2009). Homogenates were then centrifuged at $18,000 \times g$ for $20 \mathrm{~min}$, and the resulting crude membrane fraction-containing pellet was resuspended in 10 volumes of TME buffer. Protein concentrations were determined using the Bradford method (Bio-Rad). Membranes were used for MAGL and FAAH activity assays.

MAGL activity assay. MAGL activity was measured by conversion of 2-oleoylglycerol labeled with $\left[{ }^{3} \mathrm{H}\right]\left(\left[{ }^{3} \mathrm{H}\right] 2-\mathrm{OG}\right)$ in the glycerol portion of the molecule to $\left[{ }^{3} \mathrm{H}\right]$ glycerol preparations. A slightly modified procedure of that described by Rademacher et al. (2008) was used. Membranes were incubated in a final volume of $0.5 \mathrm{ml}$ TME buffer (50 mm Tris- $\mathrm{HCl}, 3.0 \mathrm{~mm} \mathrm{MgCl}_{2}, 1.0 \mathrm{~mm}$ EDTA, and $300 \mathrm{~nm}$ URB597, $\mathrm{pH} 7.4$ ) that contained $1.0 \mathrm{mg} / \mathrm{ml}$ fatty acid-free BSA and $100,000 \mathrm{dpm}\left[{ }^{3} \mathrm{H}\right] 2$-OG. Isotherms were constructed using six concentrations of 2-OG at concentrations between 10 and $500 \mu \mathrm{M}$. Incubation was performed at $30^{\circ} \mathrm{C}$, and the enzymatic reaction was stopped by the addition of $2 \mathrm{ml}$ of chloroform/methanol (1:2). After remaining at room temperature for $30 \mathrm{~min}$ with frequent mixing, 0.67 $\mathrm{ml}$ of chloroform and $0.6 \mathrm{ml}$ of water were added, and the aqueous and organic phases were separated by centrifugation at $1000 \mathrm{rpm}$ for $10 \mathrm{~min}$. The amount of $\left[{ }^{3} \mathrm{H}\right]$ in $0.5 \mathrm{ml}$ of each of the aqueous and organic phases was determined by liquid scintillation counting and conversion of $\left[{ }^{3} \mathrm{H}\right] 2$-OG to $\left[{ }^{3} \mathrm{H}\right]$ glycerol was calculated. The binding affinity $\left(K_{\mathrm{m}}\right)$ and maximal hydrolytic activity $\left(V_{\max }\right)$ values for this conversion were determined by fitting the data to a single-site Michaelis-Menten equation using GraphPad Prism (GraphPad).

FAAH activity assay. FAAH activity from hippocampal membranes was measured by conversion of AEA labeled with $\left[{ }^{3} \mathrm{H}\right]$ in the ethanolamine portion of the molecule to $\left[{ }^{3} \mathrm{H}\right]$ ethanolamine preparations as reported previously (Hill et al., 2009). The $K_{\mathrm{m}}$ of AEA for FAAH and $V_{\max }$ of FAAH for this conversion were determined by fitting the data to the Michaelis-Menten equation using GraphPad Prism (GraphPad).

Statistics. Data are mean \pm SEM. Water maze training data were analyzed with one- or two-way ANOVAs with training day as repeated measure. Probe-trial retention data were analyzed with unpaired $t$ tests, one-, two-, or three-way ANOVAs, when appropriate. Plasma corticosterone levels, hippocampal endocannabinoid content, and MAGL and FAAH activity parameters were analyzed with unpaired $t$ tests or one-way ANOVAs. Tukey-Kramer post hoc tests were used to determine the source of the detected significances, when appropriate. $p$ values of $<0.05$ were considered statistically significant. The number of rats per group is indicated in the figure legends.

\section{Results}

\section{Learning under stress enhances probe-trial retention performance}

We first sought to determine whether the different water temperatures at training influenced spatial memory performance of vehicle-treated rats.

Repeated-measures ANOVA for escape latencies to find the hidden platform during training, before drug treatment, revealed a significant effect of training day $\left(F_{(1,74)}=203.03, p<\right.$ 

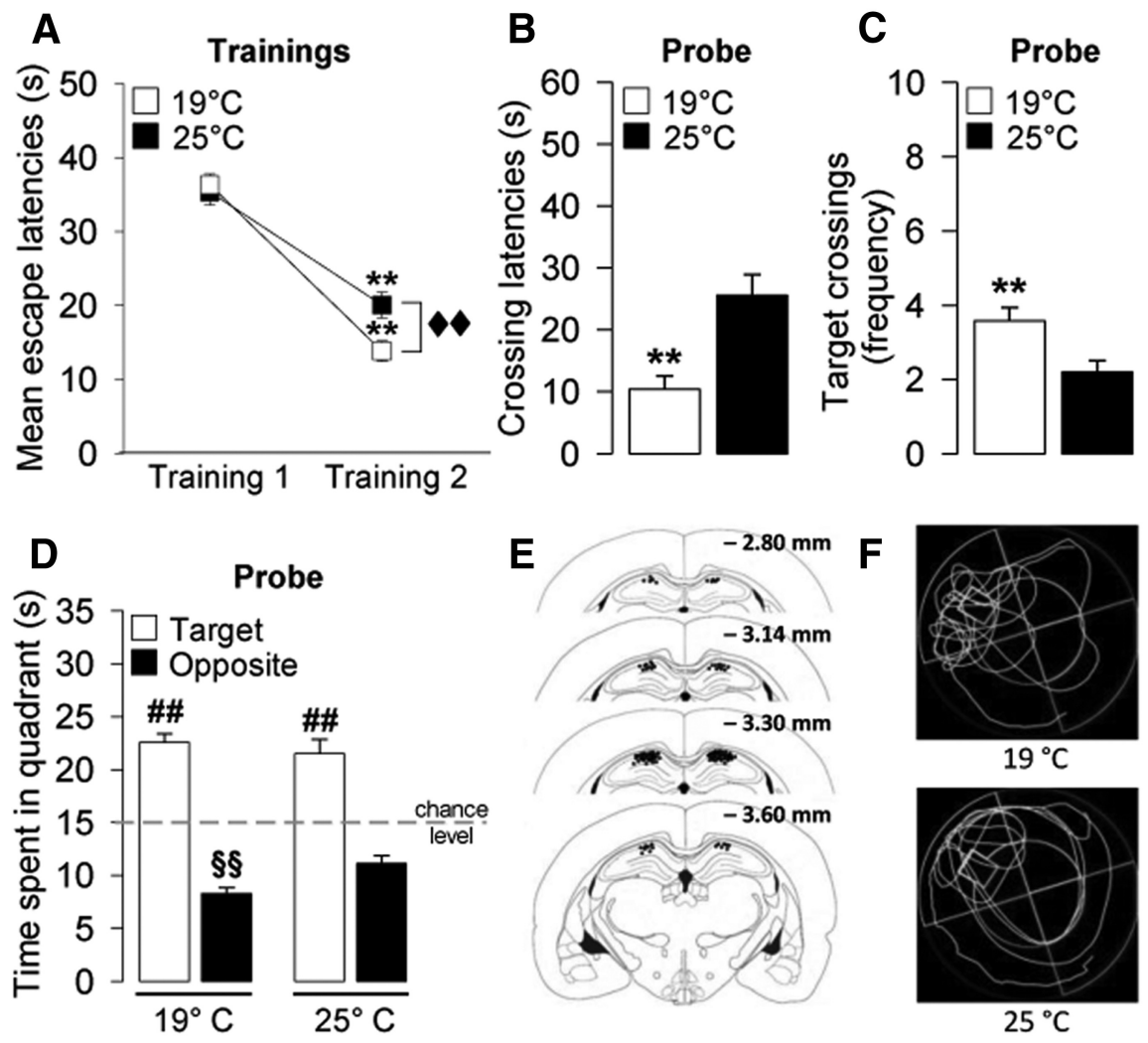

Figure 1. Effect of water temperature on training and probe performances of vehicle-treated rats. $\boldsymbol{A}$, Rats trained at either $19^{\circ} \mathrm{C}$ or $25^{\circ} \mathrm{C}$ acquired the behavioral task as indicated by a significant difference between mean escape latencies during Training 1 and Training 2. Rats trained at $19^{\circ} \mathrm{C}$ showed a better memory performance than rats trained at $25^{\circ} \mathrm{C}$ during Training $2 .{ }^{* *} p<0.01$ versus Training 1. $p<0.01$, mean escape latencies at $19^{\circ} \mathrm{C}$ versus mean escape latencies at $25^{\circ} \mathbf{C}$. $\boldsymbol{B}-\boldsymbol{D}$, The higher stress condition $\left(19^{\circ} \mathrm{C}\right)$ enhanced probe-trial retention performance in rats. Rats trained at the higher stress condition $\left(19^{\circ} \mathrm{C}\right)$ spent less time to first cross the platform location $(\boldsymbol{B})$ and performed a higher number of target crossings $(\boldsymbol{C})$ during probe compared with the group trained under the lower stress condition $\left(25^{\circ} \mathrm{C}\right) . \boldsymbol{D}$, Both experimental groups spent more time in the target quadrant than in the opposite quadrant in searching of the platform location. Rats trained at the higher stress condition spent less time in the opposite quadrant than rats trained at the lower stress condition. $\boldsymbol{E}$, Illustration of rat coronal sections showing infusion needle termination sites of the rats included in the final analyses. $\boldsymbol{F}$, Representative probe-trial swim paths of the $19^{\circ} \mathrm{C}$ and the $25^{\circ} \mathrm{C}$ groups. ${ }^{* *} p<0.01$ versus $25^{\circ} \mathrm{C}$ group. ${ }^{\# \#} p<0.01$ versus the correspondent opposite quadrant. ${ }^{\S} p<0.05$ versus opposite quadrant time of the $25^{\circ} \mathrm{C}$ group. Data are mean \pm SEM ( $n=36-40$ per group).

0.0001), confirming that the two groups progressively learned to locate the platform across the two training sessions. It also revealed a significant training day $\times$ water temperature effect $\left(F_{(1,74)}=7.38, p=0.008\right)$. Post hoc analysis indicated that rats trained at the higher stress condition $\left(19^{\circ} \mathrm{C}\right)$ had shorter escape latencies on the second day of training than those trained at $25^{\circ} \mathrm{C}(p<0.01$; Fig. $1 A)$. Thus, rats trained at the higher stress condition acquired the behavioral task better than rats trained at $25^{\circ} \mathrm{C}$.

As shown in Figure $1 B-D$, rats trained at the higher stress condition had also better probe-trial retention performance compared with rats trained at $25^{\circ} \mathrm{C}$. Unpaired $t$ tests revealed that rats trained at the higher stress condition took less time to initially cross the platform location $\left(t_{(74)}=-3.72 ; p=0.0004\right.$; Fig. $1 B$ ) and had a higher number of crossings through the platform location $\left(t_{(74)}=2.97 ; p=0.004\right.$; Fig. $\left.1 C\right)$. Two-way ANOVA for time spent searching for the platform location revealed no water temperature effect $\left(F_{(1,148)}=0.85, p=0.36\right)$ but a significant quadrant $\left(F_{(1,148)}=171.18, p<0.0001\right)$ and water temperature $\times$ quadrant interaction effect $\left(F_{(1,148)}=\right.$ $4.30, p=0.04)$. Both groups of vehicle-treated rats exhibited memory of the platform position during training, as indicated by significantly longer search times in the vicinity of the platform location (i.e., target quadrant) than in the opposite quadrant $(p<0.01$; Fig. $1 D)$. However, rats trained with the lower water temperature spent significantly less time in the opposite quadrant than rats trained with the higher water temperature $(p<0.01$; Fig. $1 D)$. No group differences were found for total swim distance on the probe trial $\left(t_{(74)}=0.35\right.$; $p=0.73$; data not shown), indicating that the two groups did not differ in motor performance.

Water maze training under the two stress conditions differentially affects plasma corticosterone levels

To assess whether the two water temperatures differentially affected plasma corticosterone levels, parallel groups of rats were trained at a water temperature of either $19^{\circ} \mathrm{C}$ or $25^{\circ} \mathrm{C}$, and trunk blood was collected $20 \mathrm{~min}$ after either day of training or immediately after the probe trial. Home cage control rats were only handled. As shown in Table 1, one-way ANOVA for plasma corticosterone levels 20 min after the first or second training day revealed a significant experimental condition effect (training day $1: F_{(2,20)}=28.47 ; p<0.0001$; training day $\left.2: F_{(2,19)}=21.41 ; p<0.0001\right)$. Rats trained with either the higher or lower water temperature had higher corticosterone levels than home cage control rats $(p<0.01$ for both comparisons). More importantly, rats trained with the lower water temperature had higher plasma corticosterone levels than those trained with the higher water temperature $(p<0.05)$, implying that the lower water temperature represented a higher stress condition. As expected, oneway ANOVA for plasma corticosterone levels measured immediately after the $60 \mathrm{~s}$ probe trial did not reveal any experimental condition effect $\left(F_{(2,22)}=1.29 ; p<0.30\right.$; Table 1) because it is well documented that plasma corticosterone peaks 20 min after the stress onset. Thus, at the time of memory retrieval, both groups of animals presented the same levels of plasma corticosterone.

The cannabinoid receptor agonist WIN55212-2 impairs probe-trial retention performance of rats trained at the higher stress condition

This experiment investigated whether the cannabinoid receptor agonist WIN55212-2 (10 or $30 \mathrm{ng}$ in $0.5 \mu \mathrm{l}$ ) infused into the dorsal hippocampus $60 \mathrm{~min}$ before the probe trial would affect retention performance and whether WIN55212-2 effects depend on the stress condition.

\section{$19^{\circ} \mathrm{C}$ water temperature}

All animals progressively learned to locate the platform across the training sessions, before drug treatment, as indicated by decreasing 
Table 1. Plasma corticosterone levels of rats trained under higher $\left(19^{\circ} \mathrm{C}\right)$ and lower stress $\left(25^{\circ} \mathrm{C}\right)$ condition and home cage rats ${ }^{a}$

\begin{tabular}{lrll}
\hline & \multicolumn{3}{c}{ Corticosterone $(\mathrm{ng} / \mathrm{ml})$} \\
\cline { 2 - 4 } Time point & Home cage & $19^{\circ} \mathrm{C}$ & $25^{\circ} \mathrm{C}$ \\
\hline 20 min after Training 1 & $76.5 \pm 16.6$ & $490.2 \pm 24.0^{\star * * *}$ & $339.6 \pm 66.4^{* *}$ \\
20 min after Training 2 & $57.6 \pm 26.5$ & $451.4 \pm 36.4^{* * * *}$ & $309.1 \pm 41.5^{* *}$ \\
Immediately after probe & $120.3 \pm 45.2$ & $174.9 \pm 29.7$ & $101.8 \pm 31.2$ \\
\hline
\end{tabular}

${ }^{a}$ Data are mean \pm SEM ( $n=5-9$ per group).

${ }^{* *} p<0.01$ versus the corresponding home cage group; $p<0.05$ versus the corresponding $25^{\circ} \mathrm{C}$ group.

mean escape latencies as training progressed $\left(F_{(1,31)}=140.88, p<\right.$ 0.0001 ; data not shown). Figure $2 A-C$ shows that WIN55212-2 administered into the dorsal hippocampus $60 \mathrm{~min}$ before the probe trial impaired retention performance of rats trained at this higher stress condition. One-way ANOVAs for crossing latencies and target crossings during the probe trial revealed a significant WIN55212-2 effect (crossing latencies: $F_{(2,31)}=3.53, p=0.04$; target crossings: $F_{(2,31)}=5.78, p=0.007$; Figure $\left.2 A, B\right)$. Post hoc analyses indicated that the 10 ng dose of WIN55212-2, but not the higher dose, significantly increased crossing latencies $(p<0.05$; Fig. $2 A$ ) and, conversely, decreased the number of crossings through the platform location $(p<0.01$; Fig. $2 B$ ). Two-way ANOVA for quadrant search times during the probe trial showed a significant quadrant effect $\left(F_{(1,62)}=109.23, p<0.0001\right)$, no WIN55212-2 effect $\left(F_{(2,62)}=9.23\right.$, $p=0.56)$, and a significant interaction between both factors $\left(F_{(2,62)}=7.37, p=0.001\right)$. Post hoc analysis revealed that all experimental groups spent more time in the target quadrant than in the opposite quadrant ( $p<0.01$; Fig. $2 C$ ), indicating that all groups exhibited memory of the platform location during training. However, WIN55212-2 significantly reduced the time spent searching for the platform location in the target quadrant ( $p<0.05$; Fig. $2 C$ ). No WIN55212-2 effect was found for total swim distance during the probe trial $\left(F_{(2,31)}=0.46 ; p=0.63\right.$; data not shown $)$.

To investigate whether the $\mathrm{CB} 1$ receptor mediates the impairing effect of WIN55212-2, the CB1 receptor antagonist AM251 $(0.28 \mathrm{ng}$ in $0.5 \mu \mathrm{l})$ was administered together with the effective dose of WIN55212-2 (10 ng) into the dorsal hippocampus $60 \mathrm{~min}$ before the probe trial. As shown in Figure $2 E, F$, two-way ANOVAs for crossing latencies and the number of target crossings during the probe trial revealed a significant main effect of WIN55212-2 (crossing latencies: $F_{(1,44)}=8.99 ; p=0.004$; target crossings: $F_{(1,44)}=5.37 ; p=0.03$ ), no AM251 effect (crossing latencies: $F_{(1,44)}=3.43 ; p=0.07$; target crossings: $F_{(1,44)}=2.81$; $p=0.10)$, and a significant interaction between WIN55212-2 and AM251 (crossing latencies: $F_{(1,44)}=5.59 ; p=0.02$; target crossings: $\left.F_{(1,44)}=7.22 ; p=0.01\right)$. Tukey's post hoc comparisons showed that WIN55212-2 alone significantly increased the initial time to cross the platform location $(p<0.01$; Fig. $2 E)$ and decreased the number of target crossings ( $p<0.01$; Fig. $2 F$ ). These effects were mediated by $\mathrm{CB} 1$ receptor activation because initial crossing latencies of rats given WIN55212-2 together with AM251 were significantly shorter than those of rats given WIN55212-2 alone ( $p<0.05$; Fig. $2 E$ ) and equivalent to those of rats given either vehicle or AM251 alone. Consistently, the number of target crossings of rats given WIN55212-2 together with AM251 was significantly higher than those of rats given WIN55212-2 alone ( $p<0.05$; Fig. $2 F$ ) and equivalent to those of rats given vehicle or AM251 alone. Three-way ANOVA for quadrant search times during the probe trial revealed no main effect of WIN55212-2 $\left(F_{(1,88)}=1.18 ; p=0.28\right)$ but significant $\operatorname{AM} 251\left(F_{(1,88)}=4.95 ; p=0.03\right)$, quadrant $\left(F_{(1,88)}=191.75 ; p<\right.$ $0.0001)$, and WIN55212-2 $\times$ AM251 $\times$ quadrant interaction ef- fects $\left(F_{(1,88)}=4.20 ; p=0.04\right.$; Fig. $\left.2 G\right)$. Rats administered vehicle into the hippocampus spent significantly more time in the target quadrant than in the opposite quadrant ( $p<0.01$; Fig. $2 G)$. As in the previous experiment, WIN55212-2 infused into the hippocampus $60 \mathrm{~min}$ before the probe trial reduced the time spent in the target quadrant $(p<0.01$; Fig. $2 G)$. Administration of AM251 alone into the hippocampus did not affect the time spent in either the target or opposite quadrant, but AM251 blocked the effects induced by WIN55212-2. Rats given combined infusions of AM251 and WIN55212-2 spent significantly more time in the target quadrant than rats given WIN55212-2 alone ( $p<0.01$; Fig. $2 G)$. Two-way ANOVA for total swim distance did not reveal a significant WIN55212-2 $\left(F_{(1,44)}=0.006 ; p=0.94\right)$, AM251 $\left(F_{(1,44)}=0.34 ; p=0.56\right)$, or WIN55212-2 $\times$ AM251 interaction effect $\left(F_{(1,44)}=0.13 ; p=0.72\right.$; data not shown $)$.

\section{$25^{\circ} \mathrm{C}$ water temperature}

WIN55212-2 infused into the hippocampus $60 \mathrm{~min}$ before the probe trial did not affect retention performance of rats trained at this lower stress condition (Fig. $2 I-K$ ). One-way ANOVAs for initial latency to cross the platform location and the number of crossings through the platform location did not reveal a significant WIN55212-2 effect $\left(F_{(2,32)}=0.50, p=0.62 ; F_{(2,32)}=0.52\right.$, $p=0.60$; respectively, Figure $2 I, J)$. Two-way ANOVA for quadrant search times during the probe trial showed a significant quadrant effect $\left(F_{(1,64)}=59.30, p<0.0001\right)$ but no WIN55212-2 effect $\left(F_{(2,64)}=0.13, p=0.88\right)$ or interaction between both factors $\left(F_{(2,64)}=0.65, p=0.52\right.$; Fig. $\left.2 K\right)$. Also, no group differences were found for total swim distance during the probe trial $\left(F_{(2,32)}=0.77 ; p=0.47\right.$; data not shown $)$.

\section{The 2-AG hydrolysis inhibitor JZL184 impairs probe-trial retention performance of rats trained at the higher stress condition}

We examined whether an increased endogenous tone of 2-AG could be involved in the modulation of probe-trial performance at the higher stress condition. To this aim, the 2-AG hydrolysis inhibitor JZL184 ( 0.1 and $1 \mu \mathrm{g}$ in $0.5 \mu \mathrm{l})$ was infused bilaterally into the dorsal hippocampus $60 \mathrm{~min}$ before the probe trial of rats trained with the two different water temperatures.

\section{$19^{\circ} \mathrm{C}$ water temperature}

All animals progressively learned to locate the platform across the two training sessions, before drug treatment, as indicated by decreasing mean escape latencies as training progressed $\left(F_{(1,26)}=\right.$ $119.11, p<0.0001$; data not shown). Similar to the effects induced by WIN55212-2, we found that the 2-AG hydrolysis inhibitor JZL184 impaired probe-trial retention performance of rats trained at this higher stress condition. One-way ANOVAs for crossing latencies and target crossings during the probe trial revealed a significant JZL184 effect (crossing latencies: $F_{(2,26)}=$ 4.28, $p=0.03$; target crossings: $F_{(2,26)}=5.99, p=0.007$; Figure $3 A, B)$. The $1 \mu \mathrm{g}$ dose of JZL184, but not the lower dose, significantly increased crossing latencies $(p<0.05$; Fig. $3 A)$, and both doses of JZL184 decreased the number of crossings through the platform location (both, $p<0.05$; Fig. $3 B$ ). As shown in Figure $3 C$, two-way ANOVA for quadrant search times during the probe trial showed a significant quadrant effect $\left(F_{(1,52)}=59.30, p<\right.$ $0.0001)$, no JZL184 effect $\left(F_{(2,52)}=0.17, p=0.84\right)$, and a significant interaction between both factors $\left(F_{(2,52)}=7.05, p=0.002\right)$. Post hoc analysis indicated that both control rats and rats treated with the lower dose of JZL184 $(0.1 \mu \mathrm{g})$ spent significantly more time in the target quadrant than in the opposite quadrant $(p<$ 
A

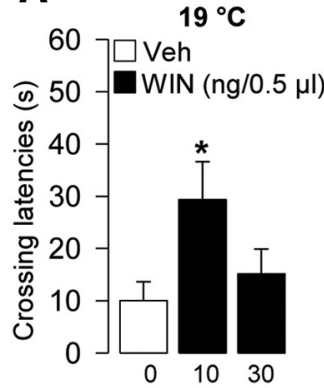

E

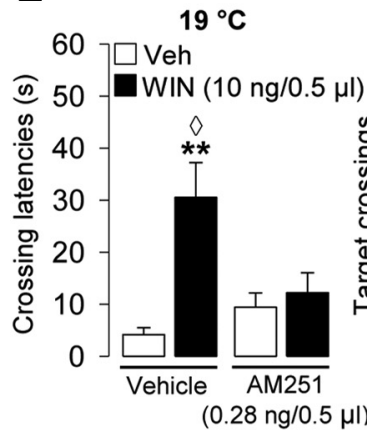

F

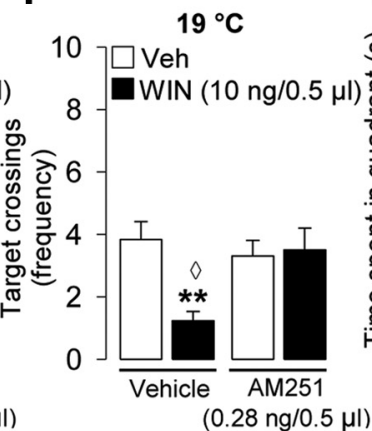

C

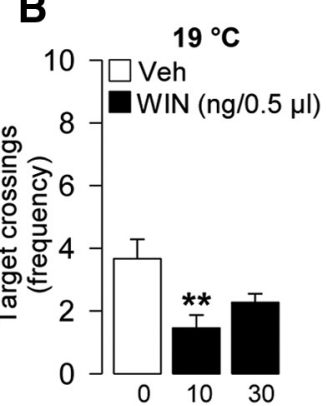

$(0.28 \mathrm{ng} / 0.5 \mu \mathrm{l})$

G
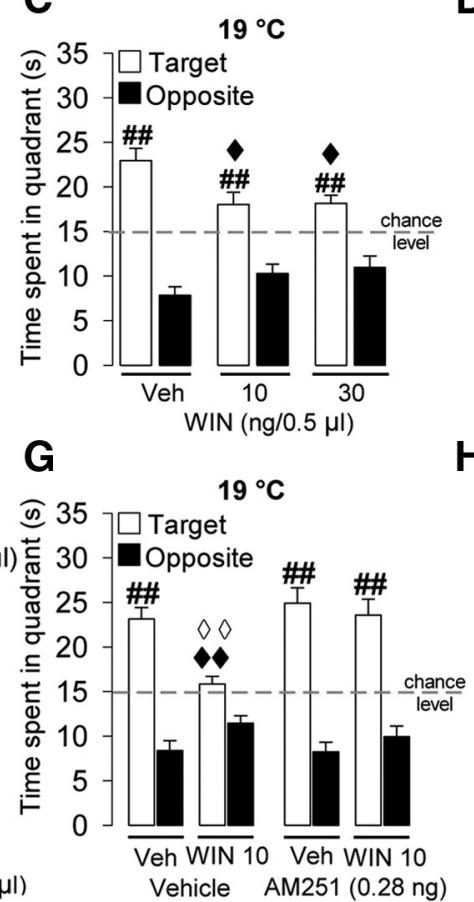

D

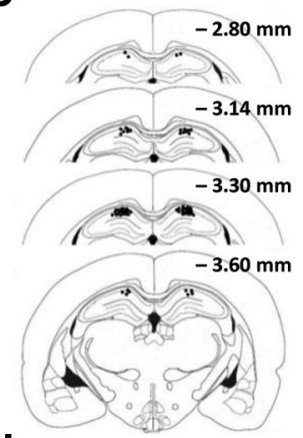

H

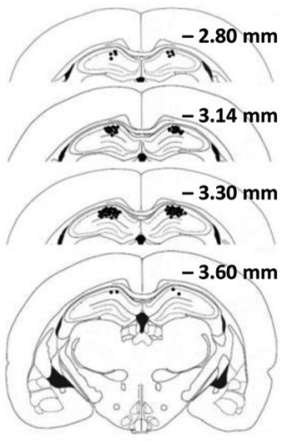

I

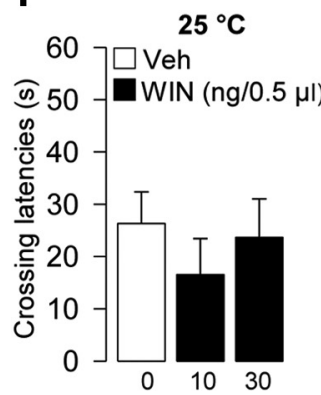

M
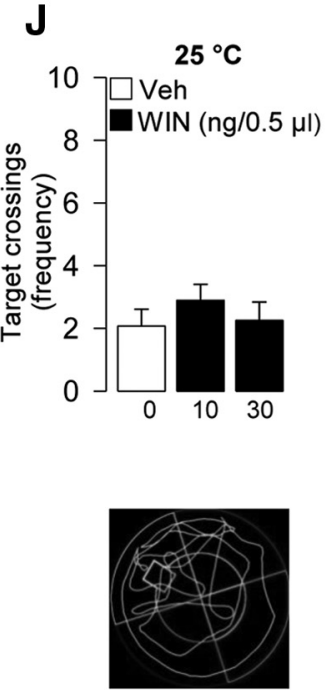

WIN 10
K
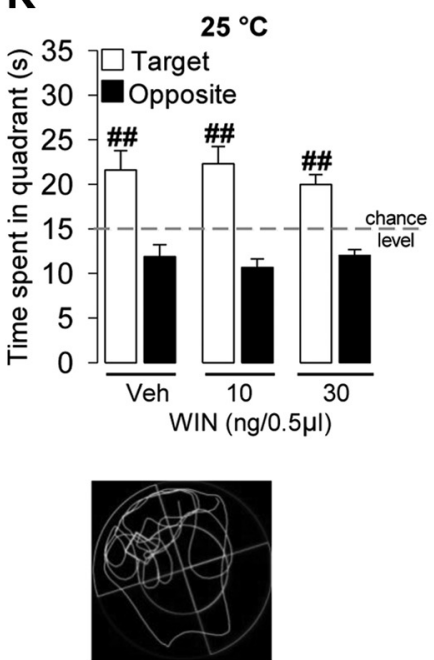

AM251
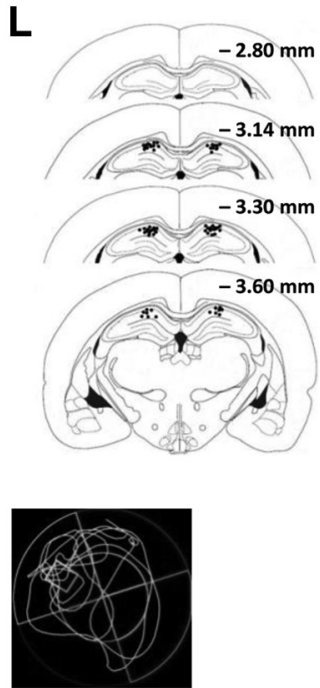

WIN 10 + AM251

Figure 2. Intrahippocampal infusions of the cannabinoid agonist WIN55212-2 (WIN) impaired probe-trial retention performance, and the CB1 receptor antagonist AM251 (0.28 ng/0.5 $\mu$ l) blocked the memory impairing effect induced by WIN (10 ng/0.5 $\mu$; WIN 10$)$, only in the higher stress condition trained group $\left(19^{\circ} \mathrm{C}\right)$. In contrast, intrahippocampal infusions of WIN did not affect spatial memory performance at the lower stress condition $\left(25^{\circ} \mathrm{C}\right)$. WIN effects on the latency to first cross the platform location $(\boldsymbol{A})$, the number of target crossings $(\boldsymbol{B})$, and the time spent in the target and opposite quadrants $(\boldsymbol{C})$ during the $1 \mathrm{~min}$ probe trial at $19^{\circ} \mathrm{C}$. $\boldsymbol{D}$, Illustration of rat coronal sections showing infusion needle termination sites of WIN-treated rats and their vehicle control group at the higher stressful condition included in the final analyses. Effects of WIN + AM251 administration on the latency to first cross the platform location $(\boldsymbol{E})$, the number of target crossings $(\boldsymbol{F})$, and the time spent in the target and opposite quadrants $(\boldsymbol{G})$ during the $1 \mathrm{~min}$ probe trial at $19^{\circ} \mathrm{C}$. $\boldsymbol{H}$, Illustration of rat coronal sections showing infusion needle termination sites of WIN-, WIN + AM251-, AM251-treated rats and their vehicle control group at the higher stressful condition included in the final analyses. WIN effects on the latency to first cross the platform location $(\boldsymbol{I})$, the number of target crossings $(\boldsymbol{J})$, and the time spent in the target and opposite quadrants $(\boldsymbol{K})$ during the 1 min probe trial at $25^{\circ} \mathrm{C}$. $L$, Illustration of rat coronal sections showing infusion needle termination sites of WIN-treated rats and their vehicle control group at the lower stressful condition included in the final analyses. $\boldsymbol{M}$, Representative probe-trial swim paths. ${ }^{*} p<0.05$ versus the correspondent vehicle (Veh) group. ${ }^{* *} p<0.01$ versus the correspondent vehicle (Veh) group. ${ }^{\# \#} p<0.01$ versus the correspondent opposite quadrant. $p<0.05$ versus target quadrant time of vehicle group. ${ }^{\star} p<0.01$ versus target quadrant time of vehicle group. ${ }^{\diamond}<0.05$ versus the correspondent WIN + AM251 group. ${ }^{\diamond} p<0.01$ versus the correspondent WIN + AM251 group. Data are mean \pm SEM ( $n=9-14$ per group).

0.01; Fig. 3C), thus indicating that they remembered the platform location. This difference was not found in animals treated with the $1 \mu \mathrm{g}$ dose of JZL184 (Fig. 3C), indicating that they did not exhibit memory for the platform location. JZL184 did not affect total swim distance during the probe trial $\left(F_{(2,26)}=2.44 ; p=\right.$ 0.11 ; data not shown).
The next experiment examined whether the JZL184 effect on probe-trial performance is mediated by $\mathrm{CB} 1$ receptor activation. To this aim, the CB1 receptor antagonist AM251 (0.28 ng/0.5 $\mu \mathrm{l})$ and the effective dose of JZL184 (1 $\mu \mathrm{g})$ were infused together into the dorsal hippocampus $60 \mathrm{~min}$ before retention testing. Figure $3 E-G$ shows the effect of JZL184 together with AM251 on probe- 
A

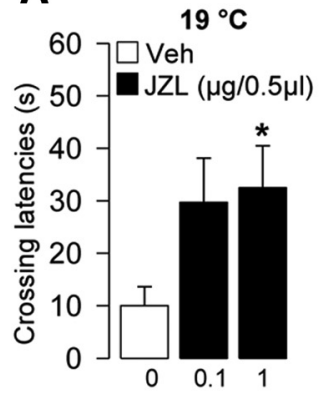

E

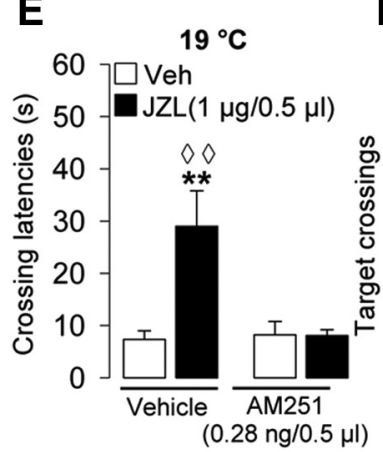

B

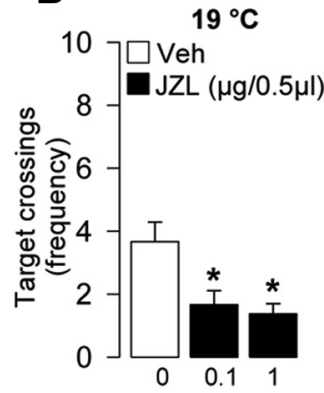

F

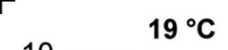
$10\rceil \square$ Veh $(1 \mu \mathrm{g} / 0.5 \mu \mathrm{l})$

G

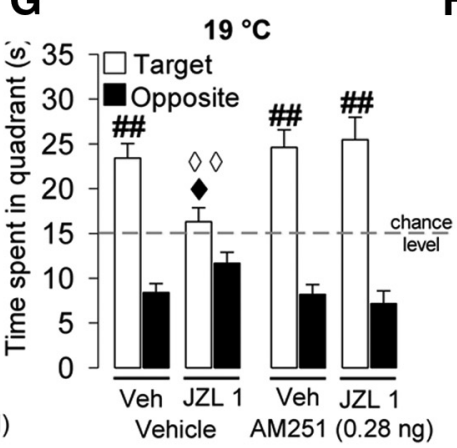

D

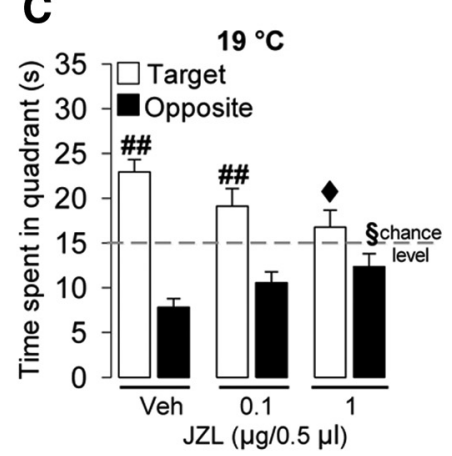

H

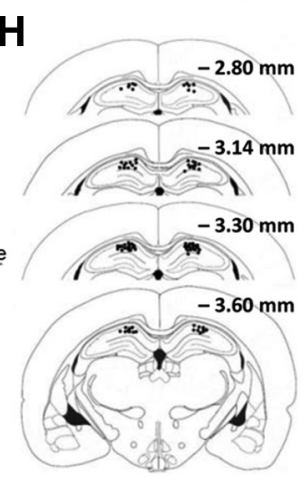

I

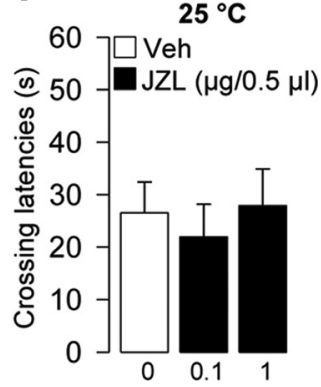

M
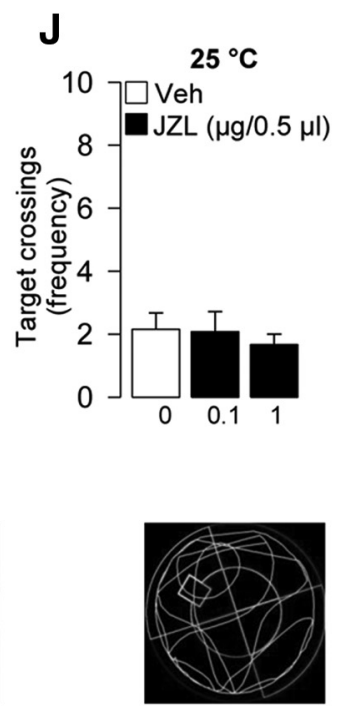

JZL 1
K

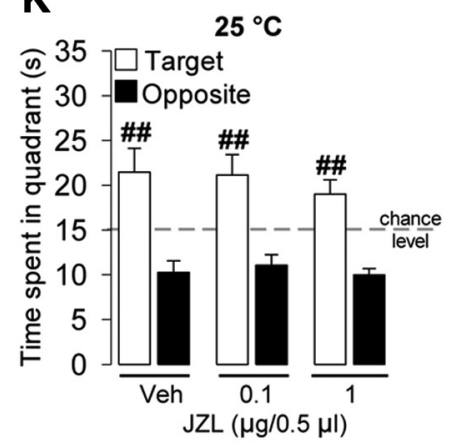

L
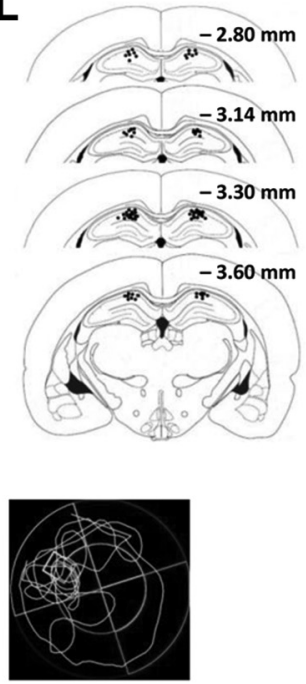

JZL 1 + AM251

Figure 3. Intrahippocampal infusions of the 2-AG hydrolysis inhibitor JZL184 (JZL) impaired probe-trial retention performance, and the (B1 receptor antagonist AM251 (0.28 ng/0.5 $\mu$ l) blocked the memory impairing effect induced by JZL ( $1 \mu \mathrm{g} / 0.5 \mu \mathrm{l}$; JZL 1$)$, only in the higher stress condition trained group $\left(19^{\circ} \mathrm{C}\right)$. In contrast, intrahippocampal infusions of JZL did not affect spatial memory performance at the lower stress condition $\left(25^{\circ} \mathrm{C}\right)$. JZL effects on the latency to first cross the platform location $(\boldsymbol{A})$, the number of target crossings $(\boldsymbol{B})$, and the time spent in the target and opposite quadrants $(\boldsymbol{C})$ during the $1 \mathrm{~min}$ probe trial at $19^{\circ} \mathrm{C} . \boldsymbol{D}$, Illustration of rat coronal sections showing infusion needle termination sites of JZL-treated rats and their vehicle control group at the higher stressful condition included in the final analyses. Effects of JZL + AM251 administration on the latency to first cross the platform location $(\boldsymbol{E})$, the number of target crossings $(\boldsymbol{F})$, and the time spent in the target and opposite quadrants $(\boldsymbol{G})$ during the 1 min probe trial at $19^{\circ} \mathrm{C}$. $\boldsymbol{H}$, Illustration of rat coronal sections showing infusion needle termination sites of JZL-, JZL + AM251-, AM251-treated rats and their vehicle control group at the higher stressful condition included in the final analyses. Effects of $J Z L$ on the latency to first cross the platform location $(I)$, the number of target crossings $(\boldsymbol{J})$, and the time spent in the target and opposite quadrants $(\boldsymbol{K})$ during the $1 \mathrm{~min}$ probe trial at $25^{\circ} \mathrm{C}$. $\boldsymbol{L}$, Illustration of rat coronal sections showing infusion needle termination sites of $J Z L$-treated rats and their vehicle control group at the lower stressful condition included in the final analyses. $M$, Representative probe-trial swim paths. ${ }^{*} p<0.05$ versus the correspondent vehicle (Veh) group. ${ }^{* *} p<0.01$ versus the correspondent vehicle (Veh) group. ${ }^{\# \#} p<0.01$ versus the correspondent opposite quadrant. ${ }^{\star} p<0.05$ versus target quadrant time of vehicle group. ${ }^{\S} p<0.05$ versus opposite quadrant time of vehicle group. $\diamond_{p}<0.01$ versus the correspondent JZL + AM251 group. Data are mean \pm SEM ( $n=8-14$ per group).

trial retention performance. Two-way ANOVAs for the crossing latencies and the number of target crossings revealed significant JZL184 (crossing latencies: $F_{(1,41)}=9.56 ; p=0.004$; target crossings: $F_{(1,41)}=5.90 ; p=0.02$ ), AM251 (crossing latencies: $F_{(1,41)}=8.24 ; p=0.007$; target crossings: $\left.F_{(1,41)}=4.28 ; p=0.04\right)$, and JZL184 $\times$ AM251 interaction effects (crossing latencies:
$F_{(1,41)}=9.79 ; p=0.003$; target crossings: $F_{(1,41)}=10.55 ; p=$ $0.002)$. JZL184 alone significantly increased the initial latency to cross the platform location $(p<0.01$; Fig. $3 E)$ and reduced the number of target crossings $(p<0.01$; Fig. $3 F)$. Initial crossing latencies of rats given JZL184 together with AM251 were significantly shorter than those of rats given JZL184 alone $(p<0.01$; 
Table 2. Hippocampal endocannabinoid 2-AG and AEA levels of rats given intrahippocampal administration of JZL184 or its vehicle ${ }^{a}$

\begin{tabular}{lcl}
\hline Treatment & 2-AG (nmol/g tissue) & AEA (pmol/g tissue) \\
\hline Vehicle & $7.5 \pm 0.6$ & $17.7 \pm 1.9$ \\
JZL184 $(1 \mu \mathrm{g} / \mathrm{side})$ & $10.7 \pm 1.0^{*}$ & $15.9 \pm 2.1$ \\
\hline
\end{tabular}

${ }^{a}$ Data are mean \pm SEM ( $n=7-10$ per group).

${ }^{*} p<0.05$ versus the corresponding vehicle group.

Fig. $3 E$ ) and equivalent to those of rats given either vehicle or AM251 alone. Consistently, the number of target crossings of rats given JZL184 and AM251 was significantly higher than those of rats given JZL184 alone ( $p<0.01$; Fig. $3 F)$ and equivalent to those of rats given vehicle or AM251 alone. Three-way ANOVA for time spent in the target and opposite quadrant revealed no main effects of JZL184 $\left(F_{(1,82)}=0.76 ; p=0.39\right)$ or AM251 $\left(F_{(1,82)}\right.$ $=1.52 ; p=0.22)$ on quadrant search times during the probe trial (Fig. $3 G)$. However, there was a significant quadrant $\left(F_{(1,82)}=\right.$ $141.89 ; p<0.0001)$ and JZL184 $\times$ AM251 $\times$ quadrant interaction effect $\left(F_{(1,82)}=7.18 ; p=0.009\right)$. Control rats spent significantly more time in the target quadrant than in the opposite quadrant $(p<0.01$; Fig. $3 G)$. JZL184 decreased the time spent in the target quadrant $(p<0.05$; Fig. $3 G)$. AM251 alone did not affect the time spent in either the target or opposite quadrant but blocked the effects induced by JZL184. Rats treated with AM251 and JZL184 spent significantly more time in the target quadrant $(p<0.01$; Fig. $3 G)$ than rats given JZL184 alone and did not differ significantly from those given either vehicle or AM251 alone. Two-way ANOVA for total swim distance did not reveal a significant JZL184 effect $\left(F_{(1,41)}=0.008 ; p=0.93\right)$, AM251 $\left(F_{(1,41)}=\right.$ $1.69 ; p=0.20)$, or JZL184 $\times$ AM251 interaction effect $\left(F_{(1,41)}=\right.$ $1.21 ; p=0.28$; data not shown).

\section{$25^{\circ} \mathrm{C}$ water temperature}

JZL184 administered into the hippocampus $60 \mathrm{~min}$ before the probe trial did not affect memory retention of rats trained at this lower stress condition (Fig. $3 I-K)$. One-way ANOVAs did not reveal a significant JZL184 effect for crossing latencies $\left(F_{(2,36)}=\right.$ $0.24, p=0.79$; Fig. $3 I)$ or target crossings $\left(F_{(2,36)}=0.37, p=0.69\right.$; Fig. $3 J)$. Two-way ANOVA for quadrant search times indicated a significant quadrant effect $\left(F_{(1,72)}=47.31, p<0.0001\right)$ but no JZL184 effect $\left(F_{(2,72)}=0.45, p=0.64\right)$ or interaction between both factors $\left(F_{(2,72)}=0.19, p=0.83\right.$; Fig. $\left.3 K\right)$. No group effects were found for total swim distance $\left(F_{(2,36)}=0.008 ; p=0.99\right.$; data not shown).

As the effectiveness of JZL184 in rats remains controversial, with some studies reporting unchanged brain 2-AG levels following systemic or local administration of JZL184 (Long et al., 2009; Wiskerke et al., 2012; Kerr et al., 2013) and other studies reporting both biochemical and behavioral effects (Sciolino et al., 2011; Oleson et al., 2012; Seillier et al., 2014), we performed an additional experiment to relate the behavioral effects of JZL184 with any change in endocannabinoid levels. Two parallel groups of rats, handled for $3 \mathrm{~d}$, were bilaterally administered, on day 4 , with the behavioral effective dose of JZL184 ( $1 \mu \mathrm{g}$ in $0.5 \mu \mathrm{l})$ or vehicle into the dorsal hippocampus and killed $60 \mathrm{~min}$ later for hippocampal dissection. As shown in Table 2, JZL184 significantly increased 2-AG levels compared with controls $\left(t_{(15)}=2.41, p=\right.$ 0.03 ) but did not affect AEA levels $\left(t_{(15)}=-59, p=0.56\right)$.

The AEA hydrolysis inhibitor URB597 does not alter probetrial retention performance

We next examined whether an increased endogenous tone of AEA would modulate probe-trial retention performance. To this aim, the AEA hydrolysis inhibitor URB597 was infused bilaterally into the hippocampus $60 \mathrm{~min}$ before the probe trial of rats trained with the two water temperatures.

\section{$19^{\circ} \mathrm{C}$ water temperature}

Repeated-measures ANOVA for escape latencies to find the hidden platform on the two training days revealed a significant effect of training day $\left(F_{(1,28)}=84.23, p<0.0001\right.$; data not shown $)$, confirming that rats progressively learned to locate the platform. Figure $4 A-C$ shows that URB597 infused into the hippocampus $60 \mathrm{~min}$ before the probe trial did not affect retention of rats trained with this higher stress condition. One-way ANOVA did not reveal any significant drug effect for crossing latencies $\left(F_{(2,28)}=0.36, p=0.70\right.$; Fig. $\left.4 A\right)$ or target crossings during the probe trial $\left(F_{(2,28)}=0.62, p=0.55\right.$; Fig. $\left.4 B\right)$. Two-way ANOVA for quadrant search times during the probe trial showed a significant quadrant effect $\left(F_{(1,56)}=82.64, p<0.0001\right)$, but no URB597 $\left(F_{(2,56)}=0.084, p=0.92\right)$, or quadrant $\times$ URB597 interaction effect $\left(F_{(2,56)}=1.56, p=0.22\right)$. Post hoc analysis revealed that all experimental groups spent more time in the target quadrant than in the opposite quadrant $(p<0.01$; Fig. $4 C)$. Also, no group differences were found for total swim distance during the probe trial $\left(F_{(2,28)}=0.52 ; p=0.60\right.$; data not shown).

\section{$25^{\circ} \mathrm{C}$ water temperature}

URB597 infused into the hippocampus $60 \mathrm{~min}$ before the probe trial also did not affect retention of rats trained at the lower stress condition (Fig. 4E-G). One-way ANOVA indicated no significant URB597 effect for initial latency to cross the platform location $\left(F_{(2,33)}=0.08, p=0.93\right.$; Fig. $\left.4 E\right)$ or for the number of crossings through the platform location $\left(F_{(2,33)}=0.69, p=0.51\right.$; Fig. $4 F)$. Two-way ANOVA for quadrant search times during the probe trial showed a significant quadrant effect $\left(F_{(1,66)}=112.69\right.$, $p<0.0001)$, but no URB597 effect $\left(F_{(2,66)}=0.16, p=0.86\right)$ or interaction between both factors $\left(F_{(2,66)}=2.35, p=0.10\right.$; Fig. $4 G)$. No group differences were found for total swim distance $\left(F_{(2,66)}=0.053 ; p=0.95\right.$; data not shown $)$.

\section{Water maze training at the higher stress condition increases} hippocampal 2-AG levels during probe-trial retention testing This experiment investigated whether the different stress levels associated to the training procedures induced any alteration in endocannabinoid 2-AG and/or AEA hippocampal levels at the time of retention testing. Parallel groups of rats were trained at a water temperature of either $19^{\circ} \mathrm{C}$ or $25^{\circ} \mathrm{C}$ and euthanized immediately after the probe trial for brain tissue dissection. Home cage control rats were handled only. As shown in Figure $5 A$, one-way ANOVA for hippocampal 2-AG levels indicated a significant experimental condition effect $\left(F_{(2,24)}=4.68 ; p=0.02\right)$. Rats trained at $19^{\circ} \mathrm{C}$ had higher $2-\mathrm{AG}$ levels immediately after the probe trial than rats trained at $25^{\circ} \mathrm{C}$ or home cage control rats $(p<0.05$ for both comparisons; Fig. 5A). Conversely, one-way ANOVA for hippocampal AEA levels did not reveal any group differences $\left(F_{(2,25)}=0.94 ; p=0.40\right.$; Fig. $\left.5 B\right)$.

\section{Water maze training at the higher stress condition alters hippocampal MAGL activity during probe-trial retention testing}

This experiment investigated whether the different stress levels associated to the training procedure $\left(19^{\circ} \mathrm{C}\right.$ or $25^{\circ} \mathrm{C}$ water temperature) induced any alteration in hippocampal MAGL and FAAH activity at the time of retention testing. Rats were euthanized immediately after the probe trial for hippocampal tissue dissection. 
A
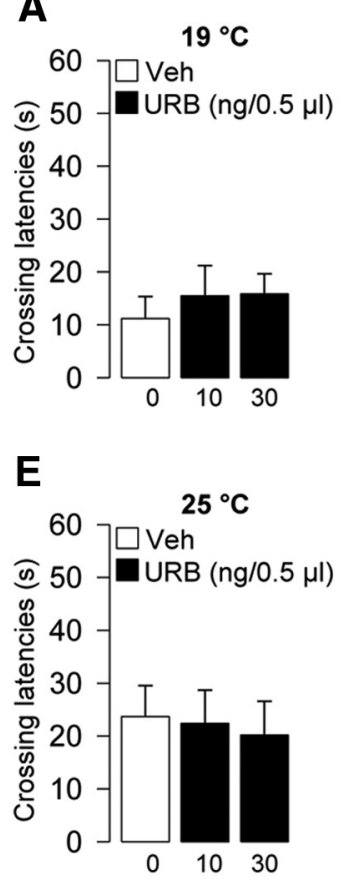

B
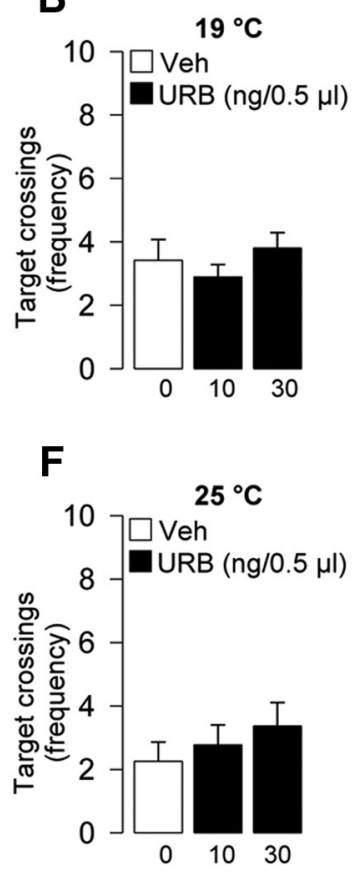

C

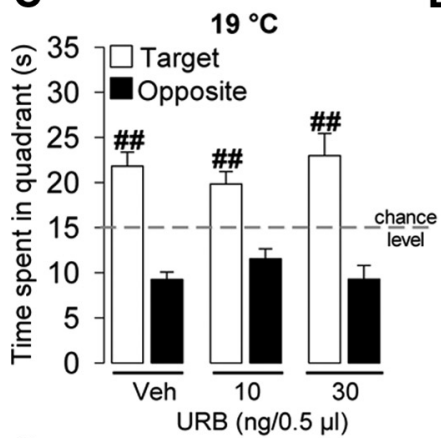

G

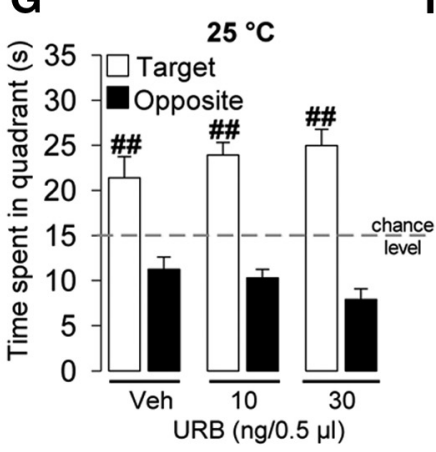

D

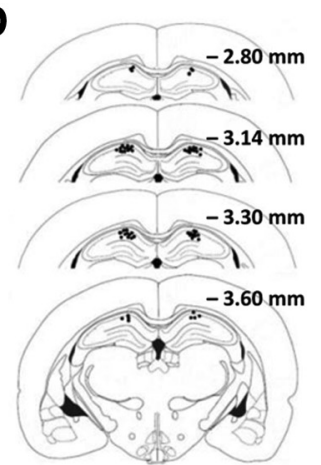

H

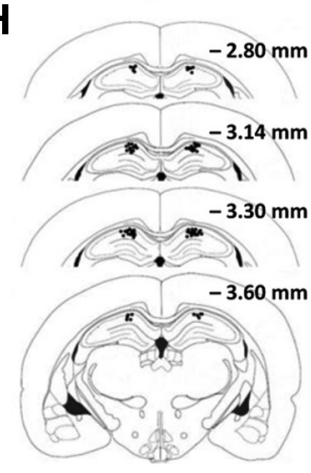

Figure 4. Intrahippocampal infusions of the AEA hydrolysis inhibitor URB597 (URB) did not affect probe-trial retention performance in either of the two different stress conditions. URB effects on the latency to first cross the platform location $(\boldsymbol{A})$, the number of target crossings $(\boldsymbol{B})$, and the time spent in the target and opposite quadrants $(\boldsymbol{C})$ during the 1 min probe trial at $19^{\circ} \mathrm{C}$. $\boldsymbol{D}, \mathrm{lllustration}$ of rat coronal sections showing infusion needle termination sites of URB-treated rats and their vehicle control group at the higher stressful condition included in the final analyses. URB effects on the latency to first cross the platform location $(\boldsymbol{E})$, the number of target crossings $(\boldsymbol{F})$, and the time spent in the target and opposite quadrants $(\boldsymbol{G})$ during the 1 min probe trial at $25^{\circ} \mathrm{C}$. $\boldsymbol{H}$, Illustration of rat coronal sections showing infusion needle termination sites of URB-treated rats and their vehicle control group at the lower stressful condition included in the final analyses. ${ }^{\#} p<0.01$ versus the correspondent opposite quadrant. Data are mean \pm SEM ( $n=9-13$ per group).

As shown in Figure 5C, one-way ANOVA for $V_{\max }$ of MAGL did not reveal any significant experimental condition effect $\left(F_{(2,8)}=1.12 ; p=0.37\right)$. Interestingly, one-way ANOVA for $K_{\mathrm{m}}$ of MAGL indicated a significant experimental condition effect $\left(F_{(2,8)}=\right.$ 7.04; $p=0.02$; Fig. $5 D$ ). Post hoc comparison indicated that rats trained at the higher stress condition had an increase in $K_{\mathrm{m}}$ value for MAGL compared with those trained at the lower stress condition or home cage control rats ( $p<0.05$, for both comparisons), indicating that this higher stress condition induced a decrease in the affinity of MAGL for its substrate. No experimental condition effect was found for the $V_{\max }\left(F_{(2,15)}=0.85 ; p=0.45\right.$; Fig. $\left.5 E\right)$ or $K_{\mathrm{m}}\left(F_{(2,15)}=0.28\right.$; $p=0.76$; Fig. $5 F)$ of FAAH.

\section{Discussion}

The present findings show that the hippocampal endocannabinoid 2-AG selectively modulates spatial memory performance of higher stressful training experience. Indeed, we found that bilateral intrahippocampal infusions of the cannabinoid receptor agonist WIN55212-2 or the 2-AG hydrolysis inhibitor JZL184, but not the AEA hydrolysis inhibitor URB597, impaired spatial memory performance of animals trained under a higher stressful condition $\left(19^{\circ} \mathrm{C}\right.$ water temperature $)$ in a spatial water maze paradigm, without inducing any effect in animals trained at the lower stressful condition $\left(25^{\circ} \mathrm{C}\right.$ water temperature). As animals were injected $60 \mathrm{~min}$ before memory retention testing, in the time window during which the training performance was retrieved, we demonstrated that boosting 2-AG signaling selectively impaired spatial memory retrieval in rats trained under the higher stress condition through the activation of hippocampal CB1 receptors. Interestingly, vehicle-treated animals trained at the higher stress condition had a better retention (probe) memory performance than animals trained under lower stress condition. Furthermore, only the higher stress training procedure induced an increase in hippocampal 2-AG levels and a reduction of MAGL affinity for its substrate, when assessed at the time of memory retrieval, without altering either AEA levels or FAAH activity in the hippocampus. These findings are in line with evidence reporting increased $2-A G$ levels after repeated exposure to stressful experiences in limbic brain regions, including the hippocampus (Patel et al., 2005b, 2009; Rademacher et al., 2008; Hill et al., 2010; Dubreucq et al., 2012). Several lines of evidence indicate that the signaling capacity of 2-AG becomes progressively increased under conditions of repeated stress, where it is thought to mediate changes in synaptic transmission and neural excitability (Patel et al., 2005b, 2009; Patel and Hillard, 2008; Hill et al., 2010; Sumislawski et al., 2011; Dubreucq et al., 2012). The present findings add to this notion by demonstrating an increase in 2-AG levels after repeated exposure to the higher stressful training condition and an augmented behavioral response to the increased 2-AG signaling. The mechanisms by which stress increases the signaling capacity of 2-AG remain unknown, deserving further investigation; however, within the amygdala, it has been demonstrated that, following exposure to repeated stress, MAGL expression translocates from the membrane to the cytosol where it would less efficiently catabolize 2-AG (Sumislawski et al., 2011).

Extensive cognitive and neurobiological research on animals, healthy human subjects, and amnesic patients indicates that the hippocampus is an important brain region involved in memory retrieval (Hirsh, 1974; Moser and Moser, 1998; Riedel et al., 1999; Eldridge et al., 2000; Squire et al., 2001; Brun et al., 2002; MatusAmat et al., 2004) and represents a primary target for stress hor- 
A
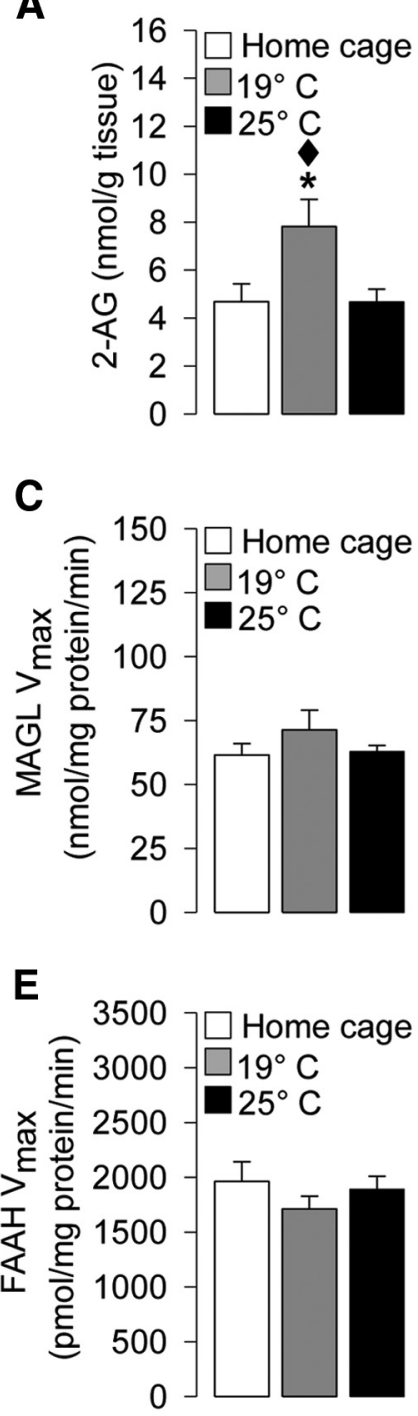

B

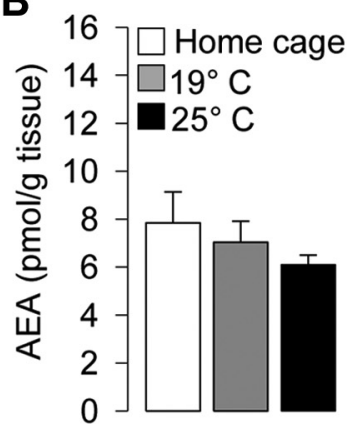

D

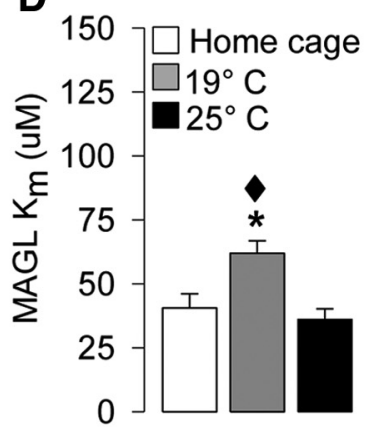

F

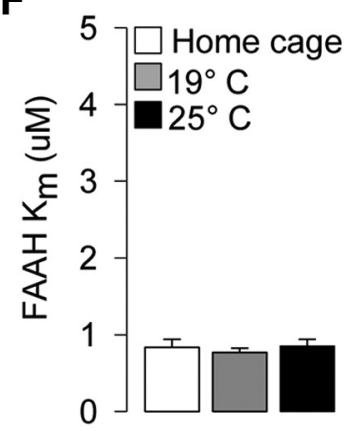

Figure 5. Effects of water temperature on hippocampal levels as follows: $\boldsymbol{A}, 2-A G$ levels (nmol/g tissue). $\boldsymbol{B}$, AEA levels (pmol/g tissue). C, MAGL maximal hydrolytic activity $\left(V_{\text {max }}\right.$; $\mathrm{nmol} / \mathrm{mg}$ protein/min). D, MAGL binding affinity $\left(K_{\mathrm{m}} ; \mu \mathrm{M}\right)$. $\boldsymbol{E}$, FAAH maximal hydrolytic activity $\left(V_{\text {max }} ; \mathrm{pmol} / \mathrm{mg}\right.$ protein/min). F, FAAH binding affinity $\left(K_{\mathrm{m}} ; \mu \mathrm{m}\right)$, as assessed immediately after probe. ${ }^{*} p<0.05$ versus the corresponding home cage group. ${ }^{\star} p<0.05$ versus the corresponding $25^{\circ} \mathrm{C}$ group. Data are mean \pm SEM ( $n=3-10$ per group).

mones (Reul and de Kloet, 1985). It is well known that stress and glucocorticoids can facilitate learning performance (Akirav et al., 2004; Salehi et al., 2010) and enhance memory consolidation (Oitzl and de Kloet, 1992; de Kloet et al., 1999; Roozendaal, 2000; Joëls and Baram, 2009). Accordingly, we found higher plasma corticosterone levels in rats trained at the higher stress condition $\left(19^{\circ} \mathrm{C}\right)$ than rats trained under the lower stress condition $\left(25^{\circ} \mathrm{C}\right)$ 20 min after training. Furthermore, rats trained under the higher stress condition showed a stronger acquisition of the behavioral task, together with a better memory retention of a strongly acquired training, relative to rats in the lower stress condition. Thus, the two experimental conditions at training elicited a different release of corticosterone depending on the level of stress associated to the water temperature; and subsequently, such hormone may have differentially affected retention processes of the two groups of rats, leading to diverse memory retrieval performances on the probe trial.

Consistent with our results, previous findings demonstrated that rats trained on a water maze task at $19^{\circ} \mathrm{C}$ exhibited better memory acquisition and retrieval than rats trained at $25^{\circ} \mathrm{C}$ (Sandi et al., 1997; Akirav et al., 2001, 2004). A more recent study reported that animals trained on a radial-arm water maze task showed an inverted U-shaped memory function according with the stressfulness of the experimental conditions used (Salehi et al., 2010). Also consistent with our current findings, it has been shown that rats trained at $19^{\circ} \mathrm{C}$ have higher plasma corticosterone levels than rats trained at $25^{\circ} \mathrm{C}$ and lower than animals trained at $16^{\circ} \mathrm{C}$ (Sandi et al., 1997; Akirav et al., 2001, 2004; Salehi et al., 2010). This facilitation of spatial learning by stress, occurring in a water maze at low water temperature, has been shown to be coupled with increased hippocampal synaptic expression of the GluA2 AMPA receptor subunit (Conboy and Sandi, 2010), which has a critical role in controlling various properties of AMPA receptors and in promoting dendritic spine formation and growth (Saglietti et al., 2007) occurring during memory consolidation (Diamond et al., 2006). Interestingly, the increased expression of GluA2 subunits is corticosterone-dependent, and preventing corticosterone release under the higher stress condition also interferes with the stress-induced facilitation of memory (Conboy and Sandi, 2010).

Our findings also show that intrahippocampal infusions of WIN55212-2 or JZL184 impair spatial memory retrieval of rats trained under the higher stress condition and that this effect is mediated by the activation of $\mathrm{CB} 1$ receptors. Conversely, the same pharmacological manipulations do not induce any effect on memory of rats trained under the lower stress condition. Therefore, we demonstrate that 2-AG is not only involved in the regulation of this hippocampus-related memory process but also that it can selectively modulate memory retrieval of high stressful experiences. In line with our findings, intrahippocampal infusions of WIN55212-2 have been reported to impair memory retrieval of high arousing test situations (Piri and Zarrindast, 2011; Segev and Akirav, 2011; Atsak et al., 2012). A pharmacologically induced enhancement of hippocampal 2-AG exerts a comparable effect (Atsak et al., 2012), whereas exogenous AEA administration in the same brain region has been shown to not alter memory retrieval performance (De Oliveira Alvares et al., 2008).

The finding that stimulating hippocampal CB1 receptors, directly with WIN55212-2 or indirectly with JZL184, impairs memory retrieval only of rats trained at the higher stress condition suggests that there are different circuits implicated in the processing of spatial information depending on the level of stress associated to the learning experience. Previous studies have suggested that spatial learning in a water maze under cold water activates the BLA, whereas increased activation of the hippocampus is detected following spatial learning under warm water (Akirav et al., 2001; Kogan and Richter-Levin, 2008). It is well known that intra-amygdala processes promote memory formation of stressful experiences in other brain regions, including the hippocampus (Roozendaal and McGaugh, 1997; McGaugh, 2000; Packard and Wingard, 2004; Morena et al., 2014). Moreover, it has been demonstrated that, once established, the spatial memory trace formed under high stress condition (i.e., water maze at $19^{\circ} \mathrm{C}$ ) is stronger compared with the trace formed under lower levels of stress (Sandi et al., 1997; Kogan and Richter-Levin, 2010; Salehi et al., 2010). However, this strong memory trace is more complex, thus more vulnerable to interference (Kogan and Richter-Levin, 2010). The dual effect of emotionality may reflect the relative contribution of different neuronal circuits and brain regions recruited to process stressful information (Adolphs et al., 1997; 
Hamann et al., 1999; Richardson et al., 2004; Smith et al., 2006). Our findings show that a physiological increase of hippocampal 2-AG levels, likely due to a reduction in the binding affinity of 2-AG for its primary degrading enzyme, selectively promotes the retrieval of stressful experience in nontreated animals. However, following an exogenous manipulation, when the endocannabinoid system is further stimulated with WIN55212-2 or JZL184, memory performance is impaired. It is likely that the memory formation of the stressful experience may have recruited neurons in different circuits, changed the location, and/or altered the functionality of CB1 receptors at cannabinoid-modulated synapses in the hippocampus, rendering this memory process more vulnerable to external manipulation at the time of memory retrieval.

Within the hippocampus, CB1 receptors are primarily located on cholecystokinin-containing interneurons (Katona et al., 1999; Marsicano and Lutz, 1999) surrounding the somata and dendrites of pyramidal neurons (Katona et al., 1999) and compared with cholecystokinin-GABA cells, glutamatergic neurons present a much lower density of CB1 receptors (Domenici et al., 2006; Kawamura et al., 2006). Furthermore, several studies have shown that hippocampal 2-AG, rather than AEA, mediates mechanisms of short- and long-term synaptic plasticity, which are involved in the modulation of memory processes (Makara et al., 2005; Straiker and Mackie, 2005; Chevaleyre et al., 2006; Hashimotodani et al., 2007; Kano et al., 2009). A growing amount of evidence shows that cannabinoids modulate behavior in an opposite way in regard to the degree of stress to which the subject is exposed (Hill and Gorzalka, 2004; Patel et al., 2005a; Fokos and Panagis, 2010; Morena and Campolongo, 2014). Importantly, both acute and chronic stress has been shown to change the synaptic effects of CB1 receptor activation. Specifically, it has been demonstrated that exposure to stress can induce a switch from CB1 receptormediated synaptic inhibition, in the form of LTD, to synaptic enhancement, in the form of LTP (Glangetas et al., 2013; Reich et al., 2013). With respect to the current study, it is important to note that, within the CA1 of the hippocampus, repeated exposure to stress has been shown to flip activation of CB1 receptors from suppressing glutamatergic transmission to promoting LTP through a sensitization of CB1 receptors on GABAergic terminals (Reich et al., 2013). On the basis of this evidence, it is tentative to speculate that the higher stress condition might have sensitized CB1 receptors on GABA cells, rather than on glutamatergic neurons, so that the endogenous release of 2-AG under these conditions actually promoted excitatory neurotransmission and ultimately a better memory recall, by preferentially suppressing GABAergic release and enhancing synaptic strength. However, it appears that this process exhibits an inverted U-shaped curve, as often seen when studying memory function, as further increasing 2-AG levels with JZL184, or strongly activating all CB1 receptors by administering the exogenous agonist WIN55212-2, produced a memory retrieval impairment. This would suggest that there is specificity to the endogenous release patterns of stress-evoked 2-AG release that in turn promote enhancement of memory retrieval. However, a broader activation of CB1 receptors following stress compromises the specificity of this process, potentially by activating also a population of CB1 receptors on excitatory terminals that ultimately impairs memory retrieval performance leading to those seen under the low stress conditions. This speculative model is consistent with electrophysiological findings demonstrating that endogenous release patterns of endocannabinoid molecules can enhance synaptic strength within the CA1 area of the hippocampus through a suppression of GABAergic activity (Carlson et al., 2002; de Oliveira Alvares et al., 2006) but demonstrating also that a broad activation of CB1 receptors inhibits synaptic strength (Misner and Sullivan, 1999). The current data indicate that this differential phenomenon is amplified by repeated exposure to stress, which in turn has significant impact on the ability of cannabinoid molecules to influence memory processes on the basis of whether they are endogenously released at specific synapses or there is broader and not selective activation of $\mathrm{CB} 1$ receptors.

Together, these findings indicate that the endocannabinoid 2-AG plays a key role in the regulation of spatial memory retrieval of stressful experiences, in the fine-tuned hippocampal neuronal activity and neurocircuitry function involved in the retrieval of stressful information, thus shedding light on the neurobiological mechanism involved in the differential impact of stress on memory processes.

\section{References}

Adolphs R, Cahill L, Schul R, Babinsky R (1997) Impaired declarative memory for emotional material following bilateral amygdala damage in humans. Learn Mem 4:291-300. CrossRef Medline

Akirav I (2011) The role of cannabinoids in modulating emotional and nonemotional memory processes in the hippocampus. Front Behav Neurosci 5:34. CrossRef Medline

Akirav I, Sandi C, Richter-Levin G (2001) Differential activation of hippocampus and amygdala following spatial learning under stress. Eur J Neurosci 14:719-725. CrossRef Medline

Akirav I, Kozenicky M, Tal D, Sandi C, Venero C, Richter-Levin G (2004) A facilitative role for corticosterone in the acquisition of a spatial task under moderate stress. Learn Mem 11:188-195. CrossRef Medline

Atsak P, Hauer D, Campolongo P, Schelling G, McGaugh JL, Roozendaal B (2012) Glucocorticoids interact with the hippocampal endocannabinoid system in impairing retrieval of contextual fear memory. Proc Natl Acad Sci U S A 109:3504-3509. CrossRef Medline

Brun VH, Otnass MK, Molden S, Steffenach HA, Witter MP, Moser MB, Moser EI (2002) Place cells and place recognition maintained by direct entorhinal-hippocampal circuitry. Science 296:2243-2246. CrossRef Medline

Campolongo P, Roozendaal B, Trezza V, Hauer D, Schelling G, McGaugh JL, Cuomo V (2009a) Endocannabinoids in the rat basolateral amygdala enhance memory consolidation and enable glucocorticoid modulation of memory. Proc Natl Acad Sci U S A 106:4888-4893. CrossRef Medline

Campolongo P, Roozendaal B, Trezza V, Cuomo V, Astarita G, Fu J, McGaugh JL, Piomelli D (2009b) Fat-induced satiety factor oleoylethanolamide enhances memory consolidation. Proc Natl Acad Sci U S A 106: 8027-8031. CrossRef Medline

Campolongo P, Morena M, Scaccianoce S, Trezza V, Chiarotti F, Schelling G, Cuomo V, Roozendaal B (2013) Novelty-induced emotional arousal modulates cannabinoid effects on recognition memory and adrenocortical activity. Neuropsychopharmacology 38:1276-1286. CrossRef Medline

Carlson G, Wang Y, Alger BE (2002) Endocannabinoids facilitate the induction of LTP in the hippocampus. Nat Neurosci 5:723-724. CrossRef Medline

Chevaleyre V, Takahashi KA, Castillo PE (2006) Endocannabinoidmediated synaptic plasticity in the CNS. Annu Rev Neurosci 29:37-76. CrossRef Medline

Conboy L, Sandi C (2010) Stress at learning facilitates memory formation by regulating AMPA receptor trafficking through a glucocorticoid action. Neuropsychopharmacology 35:674-685. CrossRef Medline

de Oliveira Alvares L, Genro BP, Vaz Breda R, Pedroso MF, Da Costa JC, Quillfeldt JA (2006) AM251, a selective antagonist of the CB1 receptor, inhibits the induction of long-term potentiation and induces retrograde amnesia in rats. Brain Res 1075:60-67. CrossRef Medline

de Oliveira Alvares L, Genro BP, Diehl F, Quillfeldt JA (2008) Differential role of the hippocampal endocannabinoid system in the memory consolidation and retrieval mechanisms. Neurobiol Learn Mem 90:1-9. CrossRef Medline

de Kloet ER, Oitzl MS, Joëls M (1999) Stress and cognition: are corticosteroids good or bad guys? Trends Neurosci 22:422-426. CrossRef Medline de Quervain DJ, Roozendaal B, McGaugh JL (1998) Stress and glucocorti- 
coids impair retrieval of long-term spatial memory. Nature 394:787-790. CrossRef Medline

de Quervain DJ, Aerni A, Schelling G, Roozendaal B (2009) Glucocorticoids and the regulation of memory in health and disease. Front Neuroendocrinol 30:358-370. CrossRef Medline

Devane WA, Hanus L, Breuer A, Pertwee RG, Stevenson LA, Griffin G, Gibson D, Mandelbaum A, Etinger A, Mechoulam R (1992) Isolation and structure of a brain constituent that binds to the cannabinoid receptor. Science 258:1946-1949. CrossRef Medline

Diamond DM, Campbell AM, Park CR, Woodson JC, Conrad CD, Bachstetter AD, Mervis RF (2006) Influence of predator stress on the consolidation versus retrieval of long-term spatial memory and hippocampal spinogenesis. Hippocampus 16:571-576. CrossRef Medline

Dincheva I, Drysdale AT, Hartley CA, Johnson DC, Jing D, King EC, Ra S, Gray JM, Yang R, DeGruccio AM, Huang C, Cravatt BF, Glatt CE, Hill MN, Casey BJ, Lee FS (2015) FAAH genetic variation enhances frontoamygdala function in mouse and human. Nat Commun 6:6395. CrossRef Medline

Domenici MR, Azad SC, Marsicano G, Schierloh A, Wotjak CT, Dodt HU, Zieglgänsberger W, Lutz B, Rammes G (2006) Cannabinoid receptor type 1 located on presynaptic terminals of principal neurons in the forebrain controls glutamatergic synaptic transmission. J Neurosci 26:57945799. CrossRef Medline

Dubreucq S, Matias I, Cardinal P, Häring M, Lutz B, Marsicano G, Chaouloff F (2012) Genetic dissection of the role of cannabinoid type-1 receptors in the emotional consequences of repeated social stress in mice. Neuropsychopharmacology 37:1885-1900. CrossRef Medline

Eldridge LL, Knowlton BJ, Furmanski CS, Bookheimer SY, Engel SA (2000) Remembering episodes: a selective role for the hippocampus during retrieval. Nat Neurosci 3:1149-1152. CrossRef Medline

Fokos S, Panagis G (2010) Effects of $\delta 9$-tetrahydrocannabinol on reward and anxiety in rats exposed to chronic unpredictable stress. J Psychopharmacol 24:767-777. CrossRef Medline

Glangetas C, Girard D, Groc L, Marsicano G, Chaouloff F, Georges F (2013) Stress switches cannabinoid type-1 (CB1) receptor-dependent plasticity from LTD to LTP in the bed nucleus of the stria terminalis. J Neurosci 33:19657-19663. CrossRef Medline

Gunduz-Cinar O, Hill MN, McEwen BS, Holmes A (2013) Amygdala FAAH and anandamide: mediating protection and recovery from stress. Trends Pharmacol Sci 34:637-644. CrossRef Medline

Hamann SB, Ely TD, Grafton ST, Kilts CD (1999) Amygdala activity related to enhanced memory for pleasant and aversive stimuli. Nat Neurosci 2:289-293. CrossRef Medline

Hashimotodani Y, Ohno-Shosaku T, Kano M (2007) Presynaptic monoacylglycerol lipase activity determines basal endocannabinoid tone and terminates retrograde endocannabinoid signaling in the hippocampus. J Neurosci 27:1211-1219. CrossRef Medline

Herkenham M, Lynn AB, Little MD, Johnson MR, Melvin LS, de Costa BR, Rice KC (1990) Cannabinoid receptor localization in brain. Proc Natl Acad Sci U S A 87:1932-1936. CrossRef Medline

Herkenham M, Lynn AB, Johnson MR, Melvin LS, de Costa BR, Rice KC (1991) Characterization and localization of cannabinoid receptors in rat brain: a quantitative in vitro autoradiographic study. J Neurosci 11:563583. Medline

Hill MN, Gorzalka BB (2004) Enhancement of anxiety-like responsiveness to the cannabinoid $\mathrm{CB}(1)$ receptor agonist $\mathrm{HU}-210$ following chronic stress. Eur J Pharmacol 499:291-295. CrossRef Medline

Hill MN, McLaughlin RJ, Morrish AC, Viau V, Floresco SB, Hillard CJ, Gorzalka BB (2009) Suppression of amygdalar endocannabinoid signaling by stress contributes to activation of the hypothalamic-pituitary-adrenal axis. Neuropsychopharmacology 34:2733-2745. CrossRef Medline

Hill MN, McLaughlin RJ, Bingham B, Shrestha L, Lee TT, Gray JM, Hillard CJ, Gorzalka BB, Viau V (2010) Endogenous cannabinoid signaling is essential for stress adaptation. Proc Natl Acad Sci U S A 107:9406-9411. CrossRef Medline

Hirsh R (1974) The hippocampus and contextual retrieval of information from memory: a theory. Behav Biol 12:421-444. CrossRef Medline

Holt W, Maren S (1999) Muscimol inactivation of the dorsal hippocampus impairs contextual retrieval of fear memory. J Neurosci 19:9054-9062. Medline

Joëls M, Baram TZ (2009) The neuro-symphony of stress. Nat Rev Neurosci 10:459-466. CrossRef Medline
Kano M, Ohno-Shosaku T, Hashimotodani Y, Uchigashima M, Watanabe M (2009) Endocannabinoid-mediated control of synaptic transmission. Physiol Rev 89:309-380. CrossRef Medline

Katona I, Sperlágh B, Sík A, Käfalvi A, Vizi ES, Mackie K, Freund TF (1999) Presynaptically located CB1 cannabinoid receptors regulate GABA release from axon terminals of specific hippocampal interneurons. J Neurosci 19:4544-4558. Medline

Kawamura Y, Fukaya M, Maejima T, Yoshida T, Miura E, Watanabe M, Ohno-Shosaku T, Kano M (2006) The CB1 cannabinoid receptor is the major cannabinoid receptor at excitatory presynaptic sites in the hippocampus and cerebellum. J Neurosci 26:2991-3001. CrossRef Medline

Kerr DM, Harhen B, Okine BN, Egan LJ, Finn DP, Roche M (2013) The monoacylglycerol lipase inhibitor JZL184 attenuates LPS-induced increases in cytokine expression in the rat frontal cortex and plasma: differential mechanisms of action. Br J Pharmacol 169:808-819. CrossRef Medline

Kogan I, Richter-Levin G (2008) Activation pattern of the limbic system following spatial learning under stress. Eur J Neurosci 27:715-722. CrossRef Medline

Kogan I, Richter-Levin G (2010) Emotional memory formation under lower versus higher stress conditions. Front Behav Neurosci 4:183. CrossRef Medline

Long JZ, Nomura DK, Cravatt BF (2009) Characterization of monoacylglycerol lipase inhibition reveals differences in central and peripheral endocannabinoid metabolism. Chem Biol 16:744-753. CrossRef Medline

Makara JK, Mor M, Fegley D, Szabó SI, Kathuria S, Astarita G, Duranti A, Tontini A, Tarzia G, Rivara S, Freund TF, Piomelli D (2005) Selective inhibition of 2-AG hydrolysis enhances endocannabinoid signaling in hippocampus. Nat Neurosci 8:1139-1141. CrossRef Medline

Marsicano G, Lafenêtre P (2009) Roles of the endocannabinoid system in learning and memory. Curr Top Behav Neurosci 1:201-230. CrossRef Medline

Marsicano G, Lutz B (1999) Expression of the cannabinoid receptor CB1 in distinct neuronal subpopulations in the adult mouse forebrain. Eur J Neurosci 11:4213-4225. CrossRef Medline

Matsuda LA, Lolait SJ, Brownstein MJ, Young AC, Bonner TI (1990) Structure of a cannabinoid receptor and functional expression of the cloned cDNA. Nature 346:561-564. CrossRef Medline

Matus-Amat P, Higgins EA, Barrientos RM, Rudy JW (2004) The role of the dorsal hippocampus in the acquisition and retrieval of context memory representations. J Neurosci 24:2431-2439. CrossRef Medline

McGaugh JL (2000) Memory: a century of consolidation. Science 287:248251. CrossRef Medline

Mishima K, Egashira N, Hirosawa N, Fujii M, Matsumoto Y, Iwasaki K, Fujiwara M (2001) Characteristics of learning and memory impairment induced by $\Delta^{9}$-tetrahydrocannabinol in rats. Jpn J Pharmacol 87:297308. CrossRef Medline

Misner DL, Sullivan JM (1999) Mechanism of cannabinoid effects on longterm potentiation and depression in hippocampal CA1 neurons. J Neurosci 19:6795-6805. Medline

Morena M, Campolongo P (2014) The endocannabinoid system: an emotional buffer in the modulation of memory function. Neurobiol Learn Mem 112C:30-43. CrossRef Medline

Morena M, Roozendaal B, Trezza V, Ratano P, Peloso A, Hauer D, Atsak P, Trabace L, Cuomo V, McGaugh JL, Schelling G, Campolongo P (2014) Endogenous cannabinoid release within prefrontal-limbic pathways affects memory consolidation of emotional training. Proc Natl Acad Sci U S A 111:18333-18338. CrossRef Medline

Moser MB, Moser EI (1998) Distributed encoding and retrieval of spatial memory in the hippocampus. J Neurosci 18:7535-7542. Medline

Niyuhire F, Varvel SA, Martin BR, Lichtman AH (2007) Exposure to marijuana smoke impairs memory retrieval in mice. J Pharmacol Exp Ther 322:1067-1075. CrossRef Medline

Oitzl MS, de Kloet ER (1992) Selective corticosteroid antagonists modulate specific aspects of spatial orientation learning. Behav Neurosci 106:62-71. CrossRef Medline

Oleson EB, Beckert MV, Morra JT, Lansink CS, Cachope R, Abdullah RA, Loriaux AL, Schetters D, Pattij T, Roitman MF, Lichtman AH, Cheer JF (2012) Endocannabinoids shape accumbal encoding of cue-motivated behavior via $\mathrm{CB} 1$ receptor activation in the ventral tegmentum. Neuron 73:360-373. CrossRef Medline

Packard MG, Wingard JC (2004) Amygdala and "emotional" modulation of the relative use of multiple memory systems. Neurobiol Learn Mem 82: 243-252. CrossRef Medline 
Patel S, Hillard CJ (2008) Adaptations in endocannabinoid signaling in response to repeated homotypic stress: a novel mechanism for stress habituation. Eur J Neurosci 27:2821-2829. CrossRef Medline

Patel S, Cravatt BF, Hillard CJ (2005a) Synergistic interactions between cannabinoids and environmental stress in the activation of the central amygdala. Neuropsychopharmacology 30:497-507. CrossRef Medline

Patel S, Roelke CT, Rademacher DJ, Hillard CJ (2005b) Inhibition of restraint stress-induced neural and behavioural activation by endogenous cannabinoid signalling. Eur J Neurosci 21:1057-1069. CrossRef Medline

Patel S, Kingsley PJ, Mackie K, Marnett LJ, Winder DG (2009) Repeated homotypic stress elevates 2-arachidonoylglycerol levels and enhances short-term endocannabinoid signaling at inhibitory synapses in basolateral amygdala. Neuropsychopharmacology 34:2699-2709. CrossRef Medline

Paxinos G, Watson C (2005) The rat brain in stereotaxic coordinates, Ed 4. San Diego: Academic.

Piri M, Zarrindast MR (2011) Modulation of WIN55212-2 state-dependent memory by alpha2-adrenergic receptors of the dorsal hippocampus. Arch Iran Med 14:389-395. CrossRef Medline

Rademacher DJ, Meier SE, Shi L, Ho WS, Jarrahian A, Hillard CJ (2008) Effects of acute and repeated restraint stress on endocannabinoid content in the amygdala, ventral striatum, and medial prefrontal cortex in mice. Neuropharmacology 54:108-116. CrossRef Medline

Reich CG, Mihalik GR, Iskander AN, Seckler JC, Weiss MS (2013) Adolescent chronic mild stress alters hippocampal CB1 receptor-mediated excitatory neurotransmission and plasticity. Neuroscience 253:444-454. CrossRef Medline

Reul JM, de Kloet ER (1985) Two receptor systems for corticosterone in rat brain: microdistribution and differential occupation. Endocrinology 117: 2505-2511. CrossRef Medline

Richardson MP, Strange BA, Dolan RJ (2004) Encoding of emotional memories depends on amygdala and hippocampus and their interactions. Nat Neurosci 7:278-285. CrossRef Medline

Riedel G, Micheau J, Lam AG, Roloff EL, Martin SJ, Bridge H, de Hoz L, Poeschel B, McCulloch J, Morris RG (1999) Reversible neural inactivation reveals hippocampal participation in several memory processes. Nat Neurosci 2:898-905. CrossRef Medline

Roozendaal B (2000) 1999 Curt P. Richter award: glucocorticoids and the regulation of memory consolidation. Psychoneuroendocrinology 25: 213-238. CrossRef Medline

Roozendaal B, McGaugh JL (1997) Basolateral amygdala lesions block the memory-enhancing effect of glucocorticoid administration in the dorsal hippocampus of rats. Eur J Neurosci 9:76-83. CrossRef Medline

Roozendaal B, Griffith QK, Buranday J, De Quervain DJ, McGaugh JL (2003) The hippocampus mediates glucocorticoid-induced impairment of spatial memory retrieval: dependence on the basolateral amygdala. Proc Natl Acad Sci U S A 100:1328-1333. CrossRef Medline

Roozendaal B, de Quervain DJ, Schelling G, McGaugh JL (2004a) A systemically administered beta-adrenoceptor antagonist blocks corticosteroneinduced impairment of contextual memory retrieval in rats. Neurobiol Learn Mem 81:150-154. CrossRef Medline

Roozendaal B, Hahn EL, Nathan SV, de Quervain DJ, McGaugh JL (2004b) Glucocorticoid effects on memory retrieval require concurrent noradrenergic activity in the hippocampus and basolateral amygdala. J Neurosci 24:8161-8169. CrossRef Medline

Ruehle S, Rey AA, Remmers F, Lutz B (2012) The endocannabinoid system in anxiety, fear memory and habituation. J Psychopharmacol 26:23-39. CrossRef Medline

Saglietti L, Dequidt C, Kamieniarz K, Rousset MC, Valnegri P, Thoumine O, Beretta F, Fagni L, Choquet D, Sala C, Sheng M, Passafaro M (2007) Extracellular interactions between GluR2 and N-cadherin in spine regulation. Neuron 54:461-477. CrossRef Medline

Salehi B, Cordero MI, Sandi C (2010) Learning under stress: the invertedU-shape function revisited. Learn Mem 17:522-530. CrossRef Medline

Sandi C, Loscertales M, Guaza C (1997) Experience-dependent facilitating effect of corticosterone on spatial memory formation in the water maze. Eur J Neurosci 9:637-642. CrossRef Medline

Sciolino NR, Zhou W, Hohmann AG (2011) Enhancement of endocannabinoid signaling with JZL184, an inhibitor of the 2-arachidonoylglycerol hydrolyzing enzyme monoacylglycerol lipase, produces anxiolytic effects under conditions of high environmental aversiveness in rats. Pharmacol Res 64:226-234. CrossRef Medline

Segev A, Akirav I (2011) Differential effects of cannabinoid receptor agonist on social discrimination and contextual fear in amygdala and hippocampus. Learn Mem 18:254-259. CrossRef Medline

Seillier A, Dominguez Aguilar D, Giuffrida A (2014) The dual FAAH/ MAGL inhibitor JZL195 has enhanced effects on endocannabinoid transmission and motor behavior in rats as compared to those of the MAGL inhibitor JZL184. Pharmacol Biochem Behav 124:153-159. CrossRef Medline

Smith AP, Stephan KE, Rugg MD, Dolan RJ (2006) Task and content modulate amygdala-hippocampal connectivity in emotional retrieval. Neuron 49:631-638. CrossRef Medline

Squire LR, Clark RE, Knowlton BJ (2001) Retrograde amnesia. Hippocampus 11:50-55. CrossRef Medline

Straiker A, Mackie K (2005) Depolarization-induced suppression of excitation in murine autaptic hippocampal neurones. J Physiol 569:501-517. CrossRef Medline

Sugiura T, Kondo S, Sukagawa A, Nakane S, Shinoda A, Itoh K, Yamashita A, Waku K (1995) 2-Arachidonoylglycerol: a possible endogenous cannabinoid receptor ligand in brain. Biochem Biophys Res Commun 215: 89-97. CrossRef Medline

Sumislawski JJ, Ramikie TS, Patel S (2011) Reversible gating of endocannabinoid plasticity in the amygdala by chronic stress: a potential role for monoacylglycerol lipase inhibition in the prevention of stress-induced behavioral adaptation. Neuropsychopharmacology 36:2750-2761. CrossRef Medline

Tsou K, Brown S, Sañudo-Peña MC, Mackie K, Walker JM (1998) Immunohistochemical distribution of cannabinoid CB1 receptors in the rat central nervous system. Neuroscience 83:393-411. CrossRef Medline

Wise LE, Thorpe AJ, Lichtman AH (2009) Hippocampal CB(1) receptors mediate the memory impairing effects of delta(9)-tetrahydrocannabinol. Neuropsychopharmacology 34:2072-2080. CrossRef Medline

Wiskerke J, Irimia C, Cravatt BF, De Vries TJ, Schoffelmeer AN, Pattij T, Parsons LH (2012) Characterization of the effects of reuptake and hydrolysis inhibition on interstitial endocannabinoid levels in the brain: an in vivo microdialysis study. ACS Chem Neurosci 3:407-417. CrossRef Medline

Wotjak CT (2005) Role of endogenous cannabinoids in cognition and emotionality. Mini Rev Med Chem 5:659-670. CrossRef Medline

Zanettini C, Panlilio LV, Alicki M, Goldberg SR, Haller J, Yasar S (2011) Effects of endocannabinoid system modulation on cognitive and emotional behavior. Front Behav Neurosci 5:57. CrossRef Medline 